\title{
Cardiomyocyte Calcium and Calcium/Calmodulin-dependent Protein Kinase II: Friends or Foes?
}

\author{
Tong Zhang, Shigeki Miyamoto, and Joan Heller Brown \\ Department of Pharmacology, University of California, San Diego, La Jolla, California 92093
}

\begin{abstract}
Calcium $\left(\mathrm{Ca}^{2+}\right)$ is a critical second messenger in cell signaling. Elevated intracellular $\mathrm{Ca}^{2+}$ can activate numerous $\mathrm{Ca}^{2+}$-regulated enzymes. These enzymes have different subcellular localizations and may respond to distinct modes of $\mathrm{Ca}^{2+}$ mobilization. In cardiac muscle, $\mathrm{Ca}^{2+}$ plays a central role in regulating contractility, gene expression, hypertrophy, and apoptosis. Many cellular responses to $\mathrm{Ca}^{2+}$ signals are mediated by $\mathrm{Ca}^{2+} /$ calmodulin-dependent enzymes, among which is the $\mathrm{Ca}^{2+}$ / calmodulin-dependent protein kinase II (CaMKII). Putative substrates for CaMKII include proteins involved in regulating $\mathrm{Ca}^{2+}$ storage and release, transcription factors, and ion channels. The major isoform of CaMKII in the heart is CaMKII $\delta$. Two cardiac splice variants, CaMKII $\delta_{\mathrm{B}}$ and $\delta_{\mathrm{C}}$, differ in whether they contain a nuclear localization sequence. Our laboratory has examined the hypothesis that the nuclear $\delta_{\mathrm{B}}$ and the cytoplasmic $\delta_{\mathrm{C}}$ isoforms respond to different $\mathrm{Ca}^{2+}$ stimuli and have distinct effects on hypertrophic cardiac growth and $\mathrm{Ca}^{2+}$ handling. We have shown that pressure overload-induced hypertrophy differentially affects the nuclear $\delta_{\mathrm{B}}$ and the cytoplasmic $\delta_{\mathrm{C}}$ isoforms of CaMKII. Additionally, using isolated myocytes and transgenic mouse models, we demonstrated that the nuclear $\mathrm{CaMKII} \delta_{\mathrm{B}}$ isoform plays a key role in cardiac gene expression associated with cardiac hypertrophy. The cytoplasmic CaMKII $\delta_{\mathrm{C}}$ isoform phosphorylates substrates involved in $\mathrm{Ca}^{2+}$ handling. Dysregulation of intracellular $\mathrm{Ca}^{2+}$ and resulting changes in excitation-contraction coupling characterize heart failure and can be induced by in vivo overexpression of CaMKII $\delta_{\mathrm{C}}$ and phosphorylation of its substrates. The differential location of CaMKII isoforms and their relative activation by physiological vs. pathological stimuli may provide a paradigm for exploring and elucidating how $\mathrm{Ca}^{2+} / \mathrm{CaMKII}$ pathways can serve as both friends and foes in the heart.
\end{abstract}

\section{Intracellular $\mathrm{Ca}^{2+}$ Regulation}

As a second messenger, $\mathrm{Ca}^{2+}$ regulates acute physiological functions, including contraction of cardiac, skeletal, and smooth muscle and release of hormones and neurotransmitters. $\mathrm{Ca}^{2+}$ also regulates more-chronic cellular responses, including cell proliferation and cell survival. Dysregulation of intracellular $\mathrm{Ca}^{2+}$ homeostasis can lead not only to loss of normal physiological control mechanisms but also to pathological changes in cell growth.

Intracellular cytosolic $\mathrm{Ca}^{2+}$ concentrations are regulated carefully to remain at $\approx 100 \mathrm{nM}$ under resting conditions. This occurs even in the face of $\mathrm{mM}$ levels of $\mathrm{Ca}^{2+}$ in the extracellular space and high $\mathrm{Ca}^{2+}$ in intracellular organelles such 
as the endoplasmic reticulum (ER). Acute increases in $\mathrm{Ca}^{2+}$ are needed to elicit physiological responses and are achieved through the actions of hormones or neurotransmitters on cell-surface receptors. In smooth muscle and secretory glands, ligands such as norepinephrine, acetylcholine, endothelin-1, and angiotensin II stimulate G protein-coupled receptors (GPCR) coupled to Gq to activate phospholipase C (PLC), catalyze phosphatidylinositol biphosphate $\left(\mathrm{PIP}_{2}\right)$ breakdown, and generate inositol 1,4,5-triphosphate $\left(\mathrm{IP}_{3}\right)$ and diacylglycerol (DAG). $\mathrm{IP}_{3}$ mobilizes $\mathrm{Ca}^{2+}$ from the ER/sarcoplasmic reticulum (SR), transiently increasing $\mathrm{Ca}^{2+}$. In skeletal muscle, nicotinic receptor activation by acetylcholine depolarizes the membrane potential to induce $\mathrm{Ca}^{2+}$ release from the SR. In cardiac muscle, $\mathrm{Ca}^{2+}$ transients occur with every heart beat. The amplitude of these transients is increased via stimulation by norepinephrine of $\beta$-adrenergic receptors coupled to Gs, which activate adenylate cyclase to increase cyclic adenosine monophospate (cAMP). Subsequent activation of protein kinase A (PKA) phosphorylates $\mathrm{Ca}^{2+}$ regulatory proteins such as voltage-dependent $\mathrm{Ca}^{2+}$ channels and phospholamban (PLB), leading to increased $\mathrm{Ca}^{2+}$ influx and releasable SR $\mathrm{Ca}^{2+}$.

\section{II. $\mathrm{Ca}^{2+}$-regulated Enzymes and $\mathrm{Ca}^{2+} / \mathrm{Calmodulin}$-dependent Protein Kinase}

Once neurotransmitters or hormones elevate $\mathrm{Ca}^{2+}$, any of a number of $\mathrm{Ca}^{2+}$-regulated enzymes - including protein kinases, protein phosphatases, phospholipases, nitric oxide synthases, cysteine protease calpains, and endonucleases - can be activated. For some of these, $\mathrm{Ca}^{2+}$ induces activation by binding to calmodulin (CaM), an intracellular $\mathrm{Ca}^{2+}$ sensor. Three $\mathrm{Ca}^{2+} /$ calmodulin-dependent enzymes have significant roles in cardiac function: $\mathrm{Ca}^{2+} /$ calmodulin-dependent protein kinase (CaM kinase or $\mathrm{CaMK}$ ), protein phosphatase $2 \mathrm{~B}$ (calcineurin), and myosin light chain kinase (MLCK). In contrast to CaMK and calcineurin, which have broad substrate specificities, MLCK is a dedicated enzyme that phosphorylates only the regulatory light chain of myosin II, modulating $\mathrm{Ca}^{2+}$ sensitivity of myofilaments and cardiac contractility (Sweeney et al., 1993) and sarcomere organization during cardiac hypertrophy (Aoki et al., 2000). This review will consider the role of $\mathrm{Ca}^{2+}$-dependent enzymes in regulating gene expression, $\mathrm{Ca}^{2+}$ handling, and apoptosis, focusing primarily on CaMK.

CaMKs are ubiquitous mediators of $\mathrm{Ca}^{2+}$ signaling (Braun and Schulman, 1995). This multifunctional serine/threonine family, consisting of CaMKI, -II, and -IV, has an extremely wide tissue distribution and is represented to varying degrees in all eukaryotic systems examined. Studies carried out over the past decade demonstrate that CaMKs can phosphorylate multiple substrates and regulate numerous cellular functions. CaMKI and CaMKIV are monomeric 
enzymes that are activated by phosphorylation through an upstream kinase (CaMK kinase) (Lee and Edelman, 1994; Tokumitsu et al., 1995). These isoforms are expressed at very low levels in the heart (Edman and Schulman, 1994; Colomer et al., 2003). In contrast, CaMKII, the major cardiac isoform, is a multimer of 6-12 subunits encoded by four separate genes: $\alpha, \beta, \gamma$, and $\delta$ (Braun and Schulman, 1995). Binding of $\mathrm{Ca}^{2+} / \mathrm{CaM}$ to CaMKII leads to its activation and subsequent autophosphorylation, rendering it autonomous (i.e., active) in the absence of $\mathrm{Ca}^{2+} / \mathrm{CaM}$ (Braun and Schulman, 1995). Several laboratories have demonstrated that the $\delta$ subunit of CaMKII predominates in the heart and that distinct splice variants of CaMKII $\delta$, characterized by the presence of a second variable domain, exist (Edman and Schulman, 1994; Baltas et al., 1995; Mayer et al., 1995). Of particular interest, the $\delta_{\mathrm{B}}$ subunit contains an 11-amino acid nuclear localization signal (NLS) that localizes it to the nucleus. In contrast, the $\delta_{\mathrm{C}}$ isoform lacks the NLS and localizes to the cytoplasm (Edman and Schulman, 1994; Srinivasan et al., 1994; Ramirez et al., 1997). Heteromultimers comprised predominantly of $\delta_{\mathrm{B}}$ subunits $\left(\mathrm{CaMKII} \delta_{\mathrm{B}}\right)$ localize to the nucleus, while those with $\delta_{\mathrm{C}}\left(\mathrm{CaMKII} \delta_{\mathrm{C}}\right)$ localize to the cytoplasm (Srinivasan et al., 1994).

\section{Role of $\mathrm{Ca}^{2+}$ Signaling in Gene Expression and Cardiac Hypertrophic Growth}

$\mathrm{Ca}^{2+}$ is a well-established regulator of transcriptional changes in gene expression (Hardingham and Bading, 1998). Changes in intracellular $\mathrm{Ca}^{2+}$ also have been suggested to mediate cardiac hypertrophic responses (for a review, see Frey et al., 2000). Modulations in $\mathrm{Ca}^{2+}$ levels would need to be transmitted to the nucleus to affect transcriptional regulation of genes associated with cardiac hypertrophy. The nuclear isoform of CaMKII $\left(\mathrm{CaMKII} \delta_{\mathrm{B}}\right)$ would, therefore, be the isoform predicted to play a predominant role in $\mathrm{Ca}^{2+}$-mediated transcriptional gene regulation. Both $\mathrm{Ca}^{2+}$ and $\mathrm{CaM}$ can translocate into the nucleus and could activate nuclear localized CaMKII (Heist and Schulman, 1998). There also is evidence for independent regulation of nuclear $\mathrm{Ca}^{2+}$ via $\mathrm{IP}_{3}$ receptors localized in the cell nucleus (Malviya and Rogue, 1998). CaMK and calcineurin have been shown to play critical and often synergistic roles in transcriptional regulation in cardiomyocytes (Passier et al., 2000) (Figure 1). There is growing evidence that the amplitude, frequency, source, and subcellular localization (spatial and/or temporal modes) of $\mathrm{Ca}^{2+}$ signals are determinants of distinct transcriptional responses (Berridge, 1997; Dolmetsch et al., 1997), allowing regulation of diverse cellular processes in response to the same second messenger $\left(\mathrm{Ca}^{2+}\right)$. In this regard, it may be important to note that CaMK is activated by high and transient $\mathrm{Ca}^{2+}$ spikes and its activity is dependent on $\mathrm{Ca}^{2+}$ spike frequency 


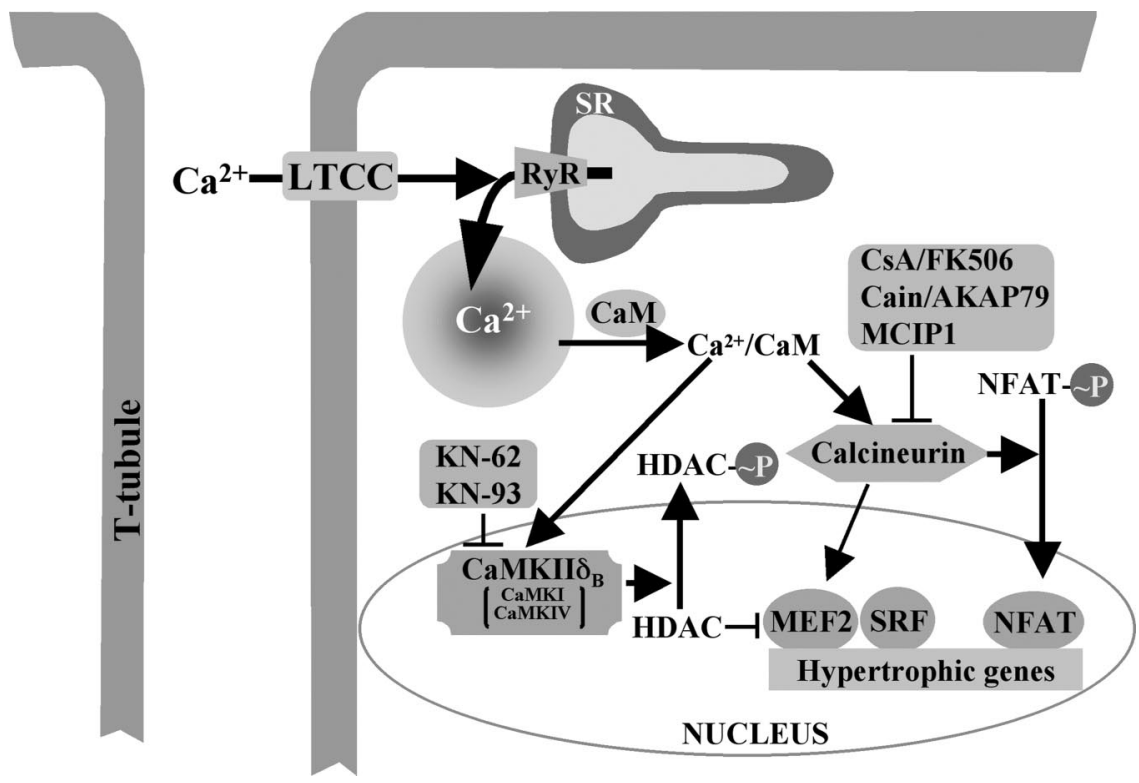

FIG. 1. Calcium $\left(\mathrm{Ca}^{2+}\right)$ signaling in cardiac gene expression and hypertrophic growth. $\mathrm{Ca}^{2+}$ binds to calmodulin (CaM), which, in turn, activates $\mathrm{Ca}^{2+} /$ calmodulin-dependent protein kinase (CaMK) or calcineurin. CaMK can phosphorylate histone deacetylase (HDAC) and dissociate it from myocyte enhancer factor 2 (MEF2) and/or serum response factor (SRF), thereby relieving HDAC inhibition of MEF2 and/or SRF transcriptional activity. Calcineurin can dephosphorylate the nuclear factor of activated $\mathrm{T}$ cells (NFAT), which enables it to translocate to the nucleus to induce hypertrophic gene expression. Calcineurin also can activate MEF2 through a post-translational mechanism. Inhibition of calcineurin by cyclosporin A (CsA)/FK506, Cain/AKAP79, or modulatory calcineurin-interacting protein (MCIP) 1 blocks calcineurin signaling pathways, while inhibition of CaMK by KN-62 or KN-93 blocks CaMK signaling pathways.

(Hudmon and Schulman, 2002), whereas calcineurin responds to low, sustained $\mathrm{Ca}^{2+}$ plateaus (Dolmetsch et al., 1997).

\section{A. CAMK SIGNALING IN GENE EXPRESSION AND CARDIAC HYPERTROPHY}

\section{The Effect of CaMK on Gene Transcription}

$\mathrm{CaMK}$ has been suggested to regulate gene expression via activation of several different transcription factors, including activation protein 1 (AP-1) (Ho et al., 1996), CAAT-enhancer binding protein (C/EBP) (Wegner et al., 1992), activating transcription factor (ATF-1) (Sun et al., 1996), serum response factor (SRF) (Misra et al., 1994), cAMP-response element binding protein (CREB) 
(Sheng et al., 1991), and myocyte enhancer factor 2 (MEF2) (Passier et al., 2000). CaMKII and CaMKIV have been shown to activate CREB by phosphorylation of Ser133 (Matthews et al., 1994). Surprisingly, CREB phosphorylation does not appear to be altered in transgenic mice expressing CaMKII $\delta_{\mathrm{B}}$ (Zhang et al., 2002) or CaMKIV (Passier et al., 2000), both of which localize to the nucleus. Therefore, phosphorylated CREB cannot account for the long-term changes in cardiac function in these mice. Another transcription factor, MEF2, is upregulated during cardiac hypertrophy (Kolodziejczyk et al., 1999; Lu et al., 2000) and has been suggested to act as a common endpoint for hypertrophic signaling pathways in the myocardium (Kolodziejczyk et al., 1999; Lu et al., 2000). Studies using transgenic overexpression of CaMKIV demonstrate that MEF2 is a downstream target for CaMKIV (Passier et al., 2000). The mechanism by which CaMK signaling activates MEF2 in vivo remains to be determined but recent studies have suggested that MEF2 interacts with class II histone deacetylases (HDACs) and other repressors that normally limit expression of MEF2-

dependent genes (Figure 1). CaMKI and CaMKIV activate MEF2 by dissociating HDACs and other repressors (Lu et al., 2000). Most recently, SRF has been shown to be activated by CaMKIV in a similar manner (i.e., by dissociating HDACs) (Davis et al., 2003). Both MEF2 and SRF activation have been demonstrated to occur in response to activation of the noncardiac CaMKI and IV isoforms. However, the ability of CaMKII to regulate HDAC - and thereby activate MEF2 and SRF - has not been explored and the selectivity of the nuclear vs. cytoplasmic CaMKII $\delta$ isoforms is undetermined. Our preliminary studies indicate that the nuclear $\mathrm{CaMKII} \delta_{\mathrm{B}}$ overcomes HDAC5-mediated repression of MEF2 activity, while the cytoplasmic CaMKII $\delta_{\mathrm{C}}$ does not (T. Zhang and J.H. Brown, unpublished data). These findings are consistent with our earlier work implicating $\mathrm{CaMKII} \delta_{\mathrm{B}}\left(\mathrm{vs} . \delta_{\mathrm{C}}\right.$ ) in control of gene expression (Ramirez et al., 1997).

\section{The Role of CaMK in Hypertrophic Growth}

Studies from a variety of in vivo preparations - including hypertensive rat hearts, coronary artery-ligated rabbit hearts, and transverse aortic-constricted (TAC) mouse hearts - have demonstrated increased CaMKII expression and activity in hypertrophied myocardium (see Table I for a summary) (Currie and Smith, 1999; Boknik et al., 2001; Hagemann et al., 2001; Zhang et al., 2003). Studies using isolated cardiomyocytes and CaMK inhibitors KN-62 or KN-93 also suggested that CaMKII was involved in cardiomyocyte hypertrophy induced by agonists such as endothelin-1, leukemia inhibitory factor (LIF), and phenylephrine (Sei et al., 1991; Ramirez et al., 1997; Kato et al., 2000; Zhu et al., 2000). Several transgenic mouse models subsequently confirmed a role for CaMK in activation of the hypertrophic gene program and development of 
hypertrophy (Table I). Transgenic mice overexpressing calmodulin were generated nearly 10 years ago and shown to develop severe cardiac hypertrophy (Gruver et al., 1993). This subsequently was demonstrated to be associated with an increase in the autonomous activity of CaMKII in vivo (Colomer and Means, 2000). Pronounced hypertrophy also develops in transgenic mice that overexpress CaMKIV (Passier et al., 2000). This is associated with specific changes in gene expression. However, CaMKIV knockout (KO) mice still are able to develop hypertrophy after TAC (Colomer et al., 2003), presumably because CaMKIV is not one of the major CaMK isoforms present in the heart (Edman and Schulman, 1994; Colomer et al., 2003).

Since hypertrophic growth is associated with a specific program of altered gene expression, and CaMKII is implicated in this response, we hypothesized that CaMKII isoforms expressed in the nucleus would selectively regulate hypertrophic transcriptional responses. In support of this, we reported that transient expression of the nuclear $\delta_{\mathrm{B}}$ isoform of CaMKII in neonatal rat ventricular myocytes induced expression of the atrial natriuretic factor (ANF) gene, an established indicator of cardiomyocyte hypertrophy, as indicated by enhanced transcriptional activation of an ANF-luciferase reporter gene and increased ANF protein (Ramirez et al., 1997). The nuclear localization signal of

TABLE I

Summary of Animal Models Showing $\mathrm{Ca}^{2+} /$ Calmodulin-dependent Protein Kinase (CaMK) Involvement in Cardiac Hypertrophy

\begin{tabular}{|c|c|c|}
\hline Animal model & Phenotype and effects & References \\
\hline Hypertensive rat models & $\begin{array}{l}\text { Cardiac hypertrophy and increased } \\
\text { CaMKII expression }\end{array}$ & Hagemann et al., 2001 \\
\hline $\begin{array}{l}\text { Spontaneously hypertensive } \\
\text { rats }\end{array}$ & $\begin{array}{l}\text { Cardiac hypertrophy and increased } \\
\text { CaMKII activity }\end{array}$ & Boknik et al., 2001 \\
\hline $\begin{array}{l}\text { Coronary artery ligation } \\
\text { rabbit }\end{array}$ & $\begin{array}{l}\text { Cardiac hypertrophy and increased } \\
\text { CaMKII activity }\end{array}$ & Currie et al., 1999 \\
\hline $\begin{array}{l}\text { Transverse aortic constricted } \\
\text { mice }\end{array}$ & $\begin{array}{l}\text { Cardiac hypertrophy and increased } \\
\text { CaMKII expression and activity }\end{array}$ & $\begin{array}{l}\text { Colomer et al., 2003; } \\
\text { Zhang et al., } 2003\end{array}$ \\
\hline Calmodulin TG mice & $\begin{array}{l}\text { Severe cardiac hypertrophy and } \\
\text { increased CaMKII activity }\end{array}$ & $\begin{array}{l}\text { Gruver } \text { et al., 1993; } \\
\quad \text { Colomer } \text { et al., } 2000\end{array}$ \\
\hline CaMKIV TG mice & $\begin{array}{l}\text { Cardiac hypertrophy through } \\
\text { MEF2 activation }\end{array}$ & Passier et al., 2000 \\
\hline CaMKII $\delta_{\mathrm{B}}$ TG mice & $\begin{array}{l}\text { Cardiac hypertrophy and dilated } \\
\text { cardiomyopathy }\end{array}$ & Zhang et al., 2002 \\
\hline
\end{tabular}

Abbreviations: TG, transgenic; MEF, myocyte enhancer factor. 
CaMKII $\delta_{\mathrm{B}}$ was shown to be required for this response, as transient expression of $\mathrm{CaMKII} \delta_{\mathrm{C}}$ did not result in enhanced ANF expression. Indeed, CaMKII heteromultimers formed predominantly of $\delta_{\mathrm{C}}$ subunits were excluded from the nucleus and failed to induce ANF expression (Ramirez et al., 1997). These findings are consistent with the observation that constitutively active CaMKI and CaMKIV, which enter the nucleus, induce a hypertrophic response in cardiomyocytes in vitro (Passier et al., 2000). We recently reported that hypertrophic growth occurs in transgenic mice that overexpress the CaMKII $\delta_{\mathrm{B}}$ isoform, which is highly concentrated in cardiomyocyte nuclei (Zhang et al., 2002).

\section{B. CALCINEURIN SIGNALING IN CARDIAC HYPERTROPHY}

\section{Calcineurin and Transcriptional Regulation}

$\mathrm{Ca}^{2+} /$ calmodulin-dependent protein phosphatase 2B (PP2B) or calcineurin is a serine/threonine protein phosphatase that is activated by sustained elevations in intracellular $\mathrm{Ca}^{2+}$. The sufficiency of calcineurin to promote cardiac hypertrophy has been demonstrated in vitro and in vivo (Molkentin et al., 1998; De Windt et al., 2000). In vitro, adenoviral expression of calcineurin is sufficient to induce hypertrophy in neonatal rat ventricular myocytes (De Windt et al., 2000). In vivo, cardiac-specific overexpression of an activated truncation mutant of calcineurin leads to profound hypertrophy that rapidly progresses to dilated heart failure by 2-3 months of age (Molkentin et al., 1998). In cardiomyocytes, calcineurin dephosphorylates the nuclear factor of activated T cells (NFAT) transcription factor, which then translocates to the nucleus and interacts with the cardiac-restricted zinc finger transcription factor GATA4 to activate the gene expression of B-type natriuretic factor, a marker for cardiac hypertrophy and heart failure (Molkentin et al., 1998). Another line of evidence for NFAT regulating cardiac transcriptional responses downstream of calcineurin is that transgenic (TG) mice overexpressing a constitutively nuclear NFATc4, one of the NFAT family members, develop profound hypertrophy within 2-3 months of age, whereas overexpression of full-length NFATc4 does not produce detectable hypertrophy (Molkentin et al., 1998). The transcription factor MEF2 also is involved in calcineurin signals through a post-translational mechanism (Blaeser et al., 2000). Two other transcription factors, NF- $\kappa$ B and Elk-1, can be regulated by calcineurin (Meyer et al., 1997; Tian and Karin, 1999).

\section{Calcineurin Involvement in Hypertrophic Responses}

A calcineurin inhibitor cyclosporin A (CsA) has been shown to attenuate the hypertrophic response induced by phenylephrine, angiotensin II, and endothelin-1 in cardiomyocytes (Molkentin et al., 1998; Zhu et al., 2000), suggesting that calcineurin is activated in response to these hypertrophic agonists. Increased 
calcineurin activity, as well as increased calcineurin mRNA and protein expression, subsequently has been demonstrated in cardiomyocytes stimulated with phenylephrine, angiotensin II, and serum (Taigen et al., 2000). Myriad studies have demonstrated that calcineurin is activated in pressure overload- and exercise-induced hypertrophy (for a review, see Molkentin, 2000). However, others have reported either no change or decreases in cardiac calcineurin activity (for a review, see Molkentin, 2000). Disparate findings also are evident in studies using systemic administration of calcineurin inhibitors, CsA, or FK506 to evaluate the role of calcineurin in cardiac hypertrophy (Olson and Williams, 2000). Morespecific inhibitors of calcineurin might provide less-equivocal information. For example, Cain/Cabin-1 or A-kinase anchoring protein 79 (AKAP79) inhibited calcineurin activity and have been shown to attenuate phenylephrine and angiotensin II-induced cardiomyocyte hypertrophy in vitro (Taigen et al., 2000) and reduced catecholamine infusion or pressure overload-induced hypertrophy in vivo (De Windt et al., 2001). In addition, the response to hypertrophic stimuli is impaired in calcineurin-deficient mice and calcineurin dominant-negative TG mice (for a review, see Wilkins and Molkentin, 2002). Similarly, cardiac-specific overexpression of modulatory calcineurin-interacting protein 1 (MCIP1) prevents the hypertrophic response to calcineurin overexpression, isoproterenol infusion, exercise, and pressure overload (for a review, see Wilkins and Molkentin, 2002). However, studies with MCIP1 also indicate differential effects, depending on the nature of the hypertrophic stimulus. Thus, in MCIP1-null mice, the hypertrophic response to activated calcineurin overexpression was exacerbated, whereas the response to pressure overload or chronic adrenergic stimulation was blunted (Vega et al., 2003).

\section{Cardiac $\mathrm{Ca}^{2+}$ Transients and Physiological $\mathrm{Ca}^{2+}$ Regulation}

In the heart, intracellular $\mathrm{Ca}^{2+}$ transients are regulated in a beat-to-beat manner (70 beats/minute in human, $>400$ beats/minute in mice), acting as transducers of excitation-contraction coupling (E-C coupling). During the cardiac action potential, $\mathrm{Ca}^{2+}$ enters the cell through voltage-dependent $\mathrm{Ca}^{2+}$ channels (L-type $\mathrm{Ca}^{2+}$ channel) and subsequently binds and activates the ryanodine receptor (RyR) on the SR to trigger further $\mathrm{Ca}^{2+}$ release (Figure 2A). This process, termed $\mathrm{Ca}^{2+}$-induced $\mathrm{Ca}^{2+}$ release (CICR), serves to amplify and coordinate the $\mathrm{Ca}^{2+}$ signal. The elemental event in $\mathrm{Ca}^{2+}$ release from the SR is the $\mathrm{Ca}^{2+}$ spark. $\mathrm{Ca}^{2+}$ sparks occur at low frequency in diastole and in a synchronized manner, which leads to large $\mathrm{Ca}^{2+}$ transients and coordinated contractions during systole. To allow for muscle relaxation between contractions, cytosolic $\mathrm{Ca}^{2+}$ must be decreased quickly. This is accomplished by the $\mathrm{Na}^{+}$/ $\mathrm{Ca}^{2+}$ exchanger (NCX), which removes $\mathrm{Ca}^{2+}$ to the extracellular space, and by the SR $\mathrm{Ca}^{2+}$ ATPase (SERCA), which mediates $\mathrm{Ca}^{2+}$ uptake into the SR. 

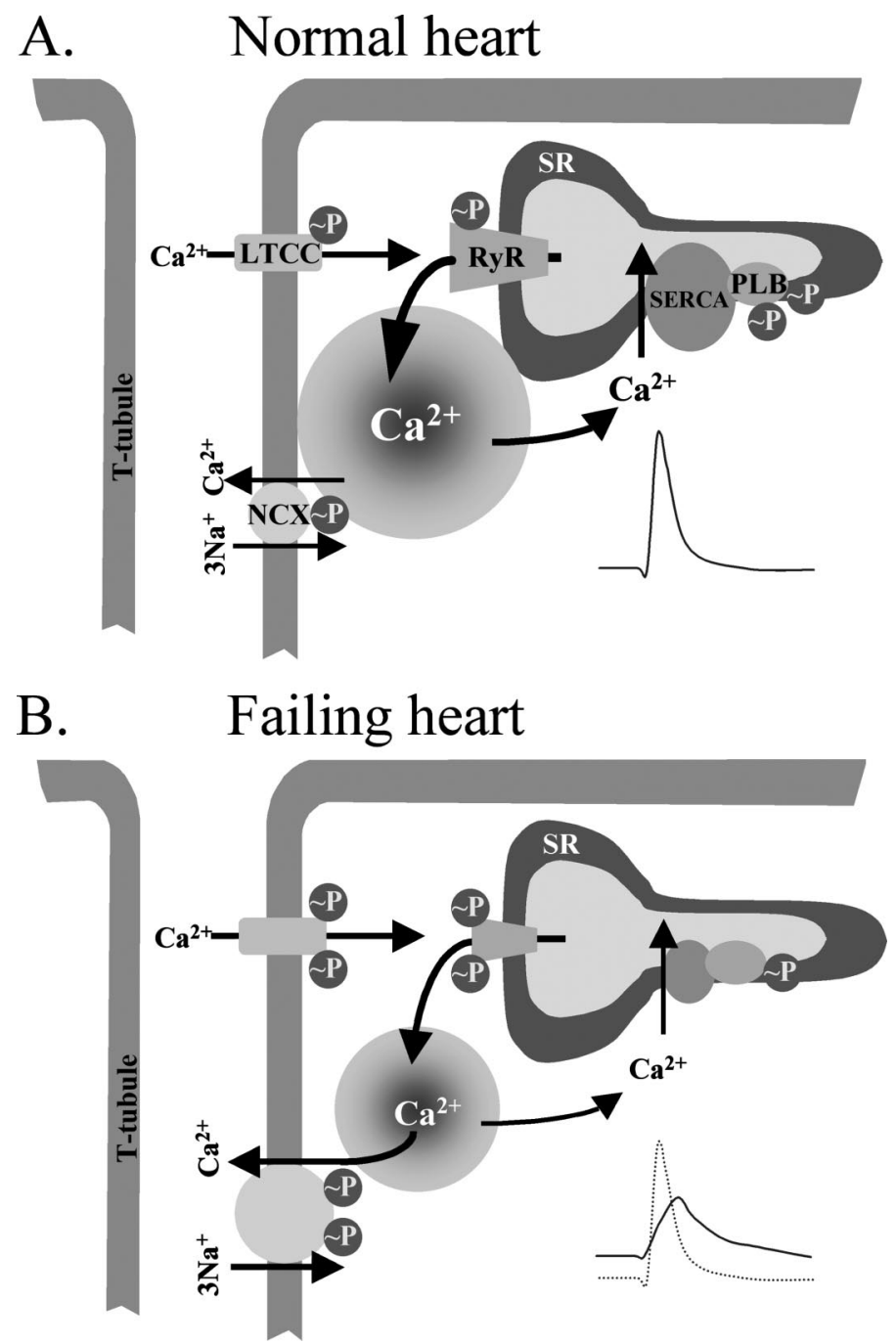

FIG. 2. $\mathrm{Ca}^{2+}$ regulation in ventricular myocytes. (A) Normal physiological $\mathrm{Ca}^{2+}$ regulation. $\mathrm{Ca}^{2+}$ entering through the L-type $\mathrm{Ca}^{2+}$ channel (LTCC) triggers $\mathrm{Ca}^{2+}$ release through ryanodinereceptor (RyR). $\mathrm{Ca}^{2+}$ reuptake into the sarcoplasmic reticulum $(\mathrm{SR})$ is mediated by the $\mathrm{SR} \mathrm{Ca}^{2+}$ ATPase (SERCA), which is negatively regulated by phospholamban (PLB). The $\mathrm{Na}^{+} / \mathrm{Ca}^{2+}$ exchanger (NCX) can serve to remove $\mathrm{Ca}^{2+}$ from the cytosol. Phosphorylations (shown as $\sim \mathrm{P}$ ) of the LTCC, RyR, NCX, and PLB regulate their functions. A normal $\mathrm{Ca}^{2+}$ transient is illustrated by the solid line. (B) Pathophysiological changes associated with heart failure, including altered expression levels of $\mathrm{Ca}^{2+}$ regulatory proteins (as indicated by difference in size compared to (A)) and altered phosphorylation state (indicated by the number of $\sim \mathrm{P}$ ). The $\mathrm{Ca}^{2+}$ transient (solid line) is smaller and slower in failing heart (compared to normal, shown as broken line in (B)). 
Two types of $\mathrm{Ca}^{2+}$ channels ( $\mathrm{L}$ and $\mathrm{T}$ ) contribute to $\mathrm{Ca}^{2+}$ influx. The L-type $\mathrm{Ca}^{2+}$ channel (LTCC) predominates in the ventricle. $\mathrm{Ca}^{2+}$ current through LTCC $\left(I_{\mathrm{CaL}}\right)$ is the most-important trigger of $\mathrm{Ca}^{2+}$ release. This current is regulated by voltage and cytosolic $\mathrm{Ca}^{2+}$ (Bers and Perez-Reyes, 1999). Stimuli that increase cAMP and activate PKA clearly enhance single-channel activity as well as whole-cell $\mathrm{Ca}^{2+}$ currents in cardiomyocytes (Bers, 2002). This contributes significantly to the positive inotropic effects of the $\beta$-adrenergic receptor pathway.

The RyR (RyR2 in heart) channel is a tetrameric structure comprised of four monomeric subunits, each of $\approx 565,000$ Daltons. $\mathrm{Ca}^{2+}$ binds to and activates the RyR to release $\mathrm{Ca}^{2+}$ from the SR. SR $\mathrm{Ca}^{2+}$ release also is regulated by $\mathrm{SR} \mathrm{Ca}^{2+}$ content, with decreases in $\mathrm{SR} \mathrm{Ca}^{2+}$ content facilitating closure of RyR (cessation of $\mathrm{Ca}^{2+}$ release) and increases in $\mathrm{SR} \mathrm{Ca}^{2+}$ content increasing the $\mathrm{Ca}^{2+}$ sensitivity of RyR to open (Bers, 2002). The RyR has been shown to form a macromolecular complex with PKA, protein phosphatases PP1 and PP2A, FK-506 binding protein (FKBP 12.6), mAKAP, and sorcin (Meyers et al., 1995; Marx et al., 2000). Recently, we showed that CaMKII also associates with the RyR (Zhang et al., 2003). RyR activity is regulated by its phosphorylation state, the best-described mechanism being RyR phosphorylation by PKA, which results in dissociation of FKBP12.6 from the channels and increased channel open probability (Marx et al., 2000).

$\mathrm{Ca}^{2+}$ uptake into the SR is mediated by SERCA. SERCA plays an important role in the declining phase of the $\mathrm{Ca}^{2+}$ transient. The activity of SERCA2a, the isoform expressed in the heart, is regulated by intracellular $\mathrm{Ca}^{2+}$ concentration and PLB. PLB is an endogenous inhibitor of SERCA that is regulated by phosphorylation. PLB is phosphorylated at Ser16 by PKA (Simmerman et al., 1986), which decreases its ability to inhibit SERCA activity. Phosphorylation of PLB by PKA thus accelerates $\mathrm{Ca}^{2+}$ uptake, contributing to the more-rapid decline of $\mathrm{Ca}^{2+}$ transients and contractions induced by $\beta$-adrenergic receptor stimulation (lusitropic effect). PLB is also phosphorylated at Thr 17 (Simmerman et al., 1986), a site for CaMKII. The effects of this phosphorylation are more controversial.

The $\mathrm{Na}^{+} / \mathrm{Ca}^{2+}$ exchanger, NCX1, is highly expressed in the heart. Under physiological conditions, the major role of $\mathrm{NCX}$ is to extrude $\mathrm{Ca}^{2+}$, although NCX can act in the reversed mode $\left(\mathrm{Ca}^{2+}\right.$ influx mode), which occurs in the presence of high intracellular $\mathrm{Na}^{+}$and high membrane voltage (Nuss and Houser, 1992). Hilgemann and colleagues have demonstrated that $\mathrm{PIP}_{2}$ is a positive regulator of NCX and suggested that this is the primary mechanism for ATP-dependent NCX activation (Hilgemann and Ball, 1996). Stimuli coupled to $\mathrm{Gq}$ and phospholipase $\mathrm{C}$ activation could affect the local cellular $\mathrm{PIP}_{2}$ level. This might contribute to the regulation of NCX activity, a hypothesis that experimentally requires validation. Although regulation of NCX activity by kinases is not 
established, it has been suggested that $\beta$-adrenergic agonists enhance NCX activity through PKA (Perchenet et al., 2000) and that $\alpha$-adrenergic agonists and phorbol ester enhance NCX activity through PKC (Iwamoto et al., 1996).

\section{Physiological Role of CaMK in Cardiomyocyte $\mathrm{Ca}^{2+}$ Handling}

CaMKII has been implicated in the modulation of several key proteins involved in acute regulation of ventricular myocyte $\mathrm{Ca}^{2+}$ homeostasis. Published studies demonstrate that CaMKII can phosphorylate RyR (Witcher et al., 1991; Hain et al., 1995), SERCA (Xu et al., 1993; Toyofuku et al., 1994), PLB (Le Peuch et al., 1979; Simmerman et al., 1986), and the LTCC or an associated regulatory protein (Dzhura et al., 2000). Thus, CaMKII has the potential to significantly affect acute $\mathrm{Ca}^{2+}$ regulation and E-C coupling in cardiomyocytes (Figure 3).

Studies using CaMKII inhibitors in isolated cardiomyocytes suggest that CaMKII is the mediator of $\mathrm{Ca}^{2+}$ current $\left(I_{\mathrm{Ca}}\right)$ facilitation (Anderson et al., 1994; Xiao et al., 1994; Yuan and Bers, 1994), although the site of CaMKII action is

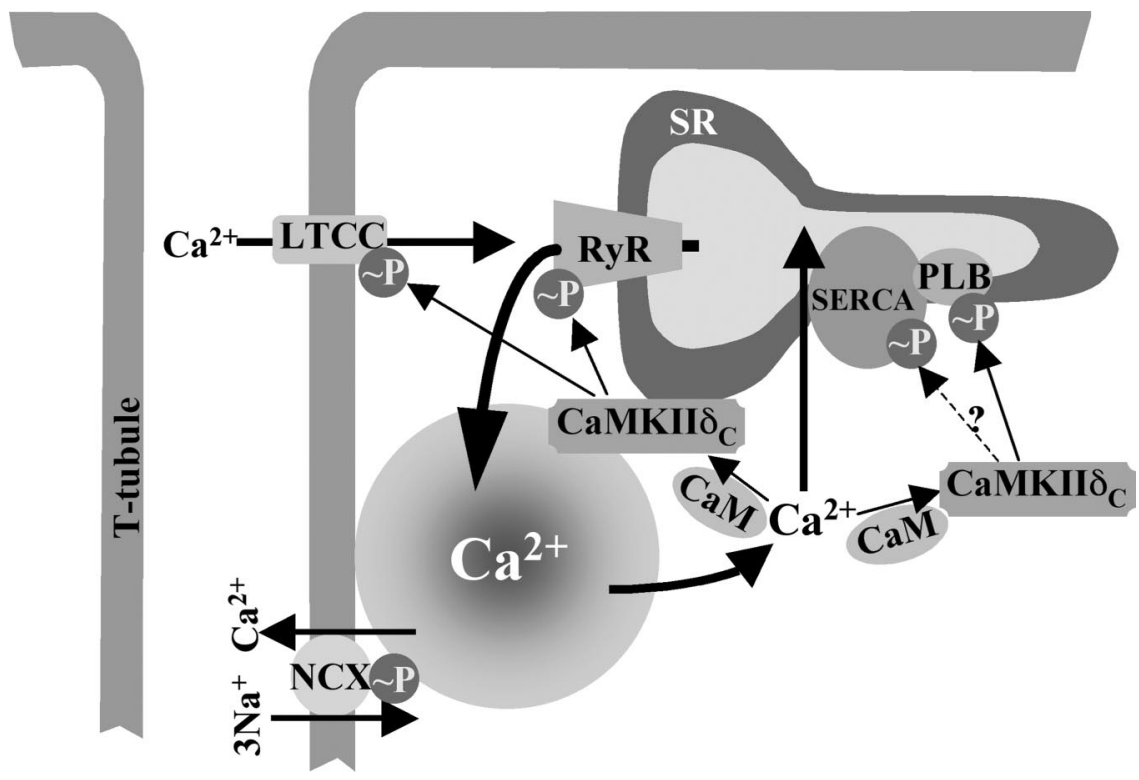

FIG. 3. Regulation of cardiomyocyte $\mathrm{Ca}^{2+}$ homeostasis by CaMKII. CaMKII can phosphorylate the RyR2 at Ser2809 (and others), SERCA2a at Ser38, PLB at Thr17, and the LTCC or an associated regulatory protein (the actual site is unknown). Most of these phosphorylations have functional consequences, indicating that CaMKII could profoundly affect $\mathrm{Ca}^{2+}$ handling in cardiomyocytes. 
not clear. It is likely that CaMKII phosphorylates the L-type $\mathrm{Ca}^{2+}$ channel complex or an associated regulatory protein, since CaMKII colocalizes with LTCC in myocytes (Xiao et al., 1994) and CaMKII can activate LTCC when it is applied to the cytoplasmic face of excised cell membrane patches (Dzhura et al., 2000). It has been reported that CaMKII is involved in the development of early after-depolarizations (EADs) and arrhythmias as a consequence of LTCC activation in vitro and in vivo (Anderson et al., 1998; Wu et al., 1999,2002).

CaMKII has been reported to phosphorylate the same site (Ser2809) as PKA on the RyR2 (Witcher et al., 1991; Marx et al., 2000; Rodriguez et al., 2003). However, the functional consequence of CaMKII-mediated phosphorylation is not yet clear. RyR2 phosphorylation by CaMKII has been suggested to alter RyR2 gating properties. While some studies indicate that CaMKII increases RyR2 open probability (Witcher et al., 1991; Hain et al., 1995), others find that CaMKII decreases RyR2 open probability (Lokuta et al., 1995). To assess the intrinsic effect of CaMKII on E-C coupling, Bers' laboratory used voltageclamped ventricular myocytes and demonstrated that, for a given $\mathrm{SR} \mathrm{Ca}^{2+}$ load and $I_{\mathrm{Ca}}$ trigger, inhibition of CaMKII by KN-93 diminished the $\mathrm{Ca}^{2+}$-dependent increase in SR $\mathrm{Ca}^{2+}$ release (relative to total SR) (Li et al., 1997). This finding supports the hypothesis that activation of CaMKII by $\mathrm{Ca}^{2+}$ transients phosphorylates RyR2 and enhances the efficacy of E-C coupling in cardiomyocytes. Whether CaMKII phosphorylation of RyR2 can dissociate FKBP12.6, as observed for PKA, is still not clear. An important recent finding from Colyer's laboratory is that CaMKII appears to phosphorylate at least four sites, in addition to Ser2809, on RyR2 in vitro (Rodriguez et al., 2003). Whether this occurs in vivo and how this alters E-C coupling have not been established.

As previously discussed, phosphorylation of PLB plays a major role in regulating cardiac SERCA activity. PLB can be phosphorylated by CaMKII at Thr17 (Le Peuch et al., 1979; Simmerman et al., 1986), a site adjacent to the PKA phosphorylation site (Ser16). Phosphorylation of PLB relieves its inhibitory effects on SERCA activity, thereby accelerating $\mathrm{Ca}^{2+}$ transport. The functional role of dual-site PLB phosphorylation has been examined extensively over the past decade. Several studies have suggested that PLB phosphorylation at Ser16, the PKA site, is a prerequisite for PLB phosphorylation at Thr17 in vivo (Luo et al., 1998) and is sufficient to mediate the maximal contractile effects of $\beta$-adrenergic stimulation (Chu et al., 2000). However, emerging evidence has shown that Thr17 phosphorylation of PLB by CaMKII can occur independently of Ser16 phosphorylation. First, it has been demonstrated in genetically targeted mice that mutation of Ser16 in PLB (S16A) does not prevent Thr17 phosphorylation (Chu et al., 2000). Second, it has been reported that electrical pacing of rat ventricular myocytes increases CaMKII-dependent phosphorylation of PLB at Thr17 in a frequency-dependent manner, without altering Ser16 phosphorylation (Hagemann et al., 2000). Third, it has been reported that an increase in Thr17 
phosphorylation can be produced by an increase in intracellular $\mathrm{Ca}^{2+}$ (with a simultaneous inhibition of phosphatases or acidosis) in the absence of $\beta$-adrenoceptor stimulation (Mundina-Weilenmann et al., 1996; Vittone et al., 1998). Finally, in CaMKII $\delta_{\mathrm{C}}$ TG mice, PLB phosphorylation at the CaMKII site was increased without increased phosphorylation of the PKA site (Zhang et al., 2003). These observations all indicate that PLB phosphorylation by CaMKII can occur independently of and serve a function distinct from that of PLB phosphorylation by PKA under physiological or pathophysiological conditions. Of particular interest, recent studies using PLB site-specific mutant mice have shown that both PLB phosphorylation sites are involved in the mechanical recovery after ischemia, with Thr17 appearing to play the major role (Said et al., 2003). In addition, it recently was reported that targeted inhibition of CaMKII in cardiac longitudinal SR transgenic mice causes selective decreases in PLB phosphorylation at Thr17 but not at Ser16 and results in cardiac dysfunction (Ji et al., 2003).

Frequency-dependent acceleration of relaxation (FDAR) is an important intrinsic physiological mechanism that contributes to faster relaxation and diastolic filling as heart rate increases. Published studies have suggested that FDAR is mediated by CaMKII rather than PKA (Bassani et al., 1995) and might be due to enhanced SR $\mathrm{Ca}^{2+}$ uptake secondary to CaMKII-mediated PLB phosphorylation (Schouten, 1990). However, while PLB would appear to be a likely target for CaMKII effects on FDAR, this response is still prominent in PLB KO mice. Moreover, it can be inhibited by the CaMKII inhibitor, KN-93 (DeSantiago et al., 2002). Thus, targets of CaMKII other than PLB must contribute to FDAR.

The question of whether SERCA function is regulated directly by CaMKII phosphorylation remains controversial. Some investigators have shown that CaMKII can directly phosphorylate cardiac SERCA (SERCA2a) on Ser38, resulting in increases in its enzymatic activity and therefore the maximal velocity $\left(\mathrm{V}_{\max }\right)$ of $\mathrm{Ca}^{2+}$ transport (Xu et al., 1993; Toyofuku et al., 1994). However, studies from other groups present contradictory findings (Odermatt et al., 1996; Reddy et al., 1996). One study failed to observe phosphorylation of SERCA2a by CaMKII (Reddy et al., 1996) and another observed CaMKII-mediated phosphorylation but did not observe stimulation of SERCA2a activity (Odermatt et al., 1996). Thus, the physiological role of SERCA2a phosphorylation by CaMKII remains unclear.

\section{Pathophysiological Changes of $\mathrm{Ca}^{2+}$ in the Heart}

A variety of stresses are imposed upon the heart by pathophysiological conditions, including high blood pressure, ischemia, infarction, and virus infection. Since cardiomyocytes are terminally differentiated and have lost their ability to proliferate, they adapt by increasing cell size, resulting in myocyte hypertrophy and cardiac enlargement. Although this is a compensatory response, 
it also serves as an independent risk factor for development of heart failure, which is characterized by the heart's inability to generate sufficient force for blood ejection. The failing heart exhibits not only structural changes but also marked alterations in $\mathrm{Ca}^{2+}$ regulatory protein expression and phosphorylation. $\mathrm{Ca}^{2+}$ transients in ventricular myocytes isolated from failing hearts are generally of reduced amplitude and characterized by slower times to peak and to decline. The diastolic level of $\mathrm{Ca}^{2+}$ is higher in failing vs. normal heart. Changes in expression levels and activity of several $\mathrm{Ca}^{2+}$ regulatory proteins are thought to underlie the dysregulation of $\mathrm{Ca}^{2+}$ transients in heart failure (Figure 2B). Diminished $\mathrm{Ca}^{2+}$ transients are major determinants of the decreased cellular contractile function. Indeed, $\mathrm{Ca}^{2+}$ dysregulation, with resultant changes in E-C coupling, has been suggested as a causal mechanism of heart failure. $\mathrm{Ca}^{2+}$ dysregulation may contribute to cardiomyocyte apoptosis (e.g., via mitochondrial $\mathrm{Ca}^{2+}$ overloading or calpain activation), leading to progressive loss of cardiomyocytes. Myocyte cell death is not compensated by myocyte cell replacement and, accordingly, myocyte loss is considered to contribute to the development of heart failure.

Furthermore, less $\mathrm{Ca}^{2+}$ release is induced by a given $\mathrm{Ca}^{2+}$ current in heart failure, a phenomenon referred to as decreased E-C coupling gain (Gomez et al., 2001). Decreased RyR expression, observed in numerous models of heart failure, could contribute to this. However, as described earlier, RyR function is also highly regulated by its phosphorylation. RyR hyperphosphorylation is observed in heart failure (Marks, 2000; Marx et al., 2000). RyR hyperphosphorylation results in the dissociation of FKBP12.6 from RyR, enhancing $\mathrm{Ca}^{2+}$ leakage during diastole and thereby decreasing the pool of $\mathrm{Ca}^{2+}$ available for release during the contractile cycle (Marks, 2000; Reiken et al., 2003a). Therefore, RyR hyperphosphorylation has been suggested to contribute to the decrease in E-C coupling gain in heart failure through the decrease in $\mathrm{SR} \mathrm{Ca}^{2+}$ loading. The maladaptive effects of RyR hyperphosphorylation may be one reason that chronic $\beta$ blockade improves cardiac contractility and prolongs survival in patients with heart failure. Indeed, recent data indicate that $\beta$ blockade normalizes the phosphorylation status of RyR, resulting in RyR stabilization and decreased $\mathrm{Ca}^{2+}$ leakage from the SR in both animal models and failing human heart (Doi et al., 2002; Reiken et al., 2003b). In addition to this hypothesized mechanism, spatial remodeling of $\mathrm{T}$ tubules (decreased number of $\mathrm{T}$ tubules) and/or the dyad (i.e., distance between LTCC and RyR) have been postulated as mechanisms for the decreased E-C coupling gain (Gomez et al., 2001).

No changes in peak $\mathrm{Ca}^{2+}$ currents are observed in most studies of heart failure (Benitah et al., 2002), although channel density has been suggested to be reduced (He et al., 2001). Increased open probability of LTCC, perhaps as a result of increased basal phosphorylation, might compensate for the decreased channel density (Schroder et al., 1998; X. Chen et al., 2002). The functional 
contribution of changes in $\mathrm{Ca}^{2+}$ currents to heart failure requires further investigation.

$\mathrm{SR} \mathrm{Ca}^{2+}$ uptake is decreased in many animal models of heart failure. This defect, like increased diastolic $\mathrm{Ca}^{2+}$ leak through phosphorylated RyR, would diminish the releasable $\mathrm{Ca}^{2+}$ pool and thus contribute to impaired contractile function. Decreases in SR $\mathrm{Ca}^{2+}$ uptake also contribute to the prolonged $\mathrm{Ca}^{2+}$ transients observed in cardiomyocytes from failing heart. A mechanistic basis for the decreased $\mathrm{Ca}^{2+}$ uptake is diminished SERCA protein expression, observed in some, but not all, experimental models of heart failure (Movsesian et al., 1994; Schwinger et al., 1995). In support of a pathophysiological role for decreased SERCA expression, recent evidence indicates that adenoviral SERCA gene delivery improves cellular contractile function and $\mathrm{Ca}^{2+}$ transients in human heart failure (Del Monte et al., 2002).

PLB generally is not decreased to the same extent as SERCA in heart failure; thus, there is a lower ratio of SERCA/PLB and enhanced SERCA inhibition in heart failure (Houser et al., 2000). PLB phosphorylation also appears to be decreased (Huang et al., 1999; Houser et al., 2000), providing another mechanism for enhanced SERCA inhibition in heart failure. Interestingly, recent evidence indicates that a mutation in PLB can, by itself, lead to human heart failure (Schmitt et al., 2003). Development of PLB inhibitors therefore has been touted as a promising therapeutic strategy to improve SR $\mathrm{Ca}^{2+}$ content and other cellular defects in heart failure (Chien et al., 2003).

The role of NCX in removing cytosolic $\mathrm{Ca}^{2+}$ gains importance in the face of decreased SR $\mathrm{Ca}^{2+}$ uptake in heart failure. In many, but not all, cases (for a review, see Sipido et al., 2002), NCX is upregulated in heart failure. This is thought to be a compensatory response to prevent $\mathrm{Ca}^{2+}$ overloading. Recently, it has been reported that NCX is hyperphosphorylated by PKA, resulting in increased activity of the exchanger in failing heart (Wei et al., 2003). While increased NCX activity initially would be adaptive, excessive or sustained NCX activation could further contribute to decreased $\mathrm{SR} \mathrm{Ca}^{2+}$ content by removing cytosolic $\mathrm{Ca}^{2+}$, diminishing systolic $\mathrm{Ca}^{2+}$ transients and contractile function.

\section{Pathophysiological Role of CaMK in the Heart}

\section{A. ROLE OF CAMK IN THE DEVELOPMENT OF HEART FAILURE}

Changes in CaMKII have been associated with development of heart failure. It has been reported that CaMKII activity is increased $\approx 3$-fold and that CaMKII expression is increased $\approx 2$-fold in human failing hearts with dilated cardiomyopathy (Hoch et al., 1999; Kirchhefer et al., 1999). Conversely, in a rat heart failure model induced by myocardial infarction (Netticadan et al., 2000) and in 
a canine model of heart failure produced by intracoronary microembolization (Mishra et al., 2003), CaMKII activity and expression are reduced. We and others observed that, in the TAC-induced hypertrophy mouse model, there is not only acute CaMKII activation but also an increase in CaMKII $\delta_{\mathrm{C}}$ expression that is sustained for at least 1 week (Colomer et al., 2003; Zhang et al., 2003). Upregulation and activation of CaMKII have been correlated with changes in cardiac function (cardiac index and ejection fraction) in patients (Hoch et al., 1999; Kirchhefer et al., 1999). Sustained CaMKII activation could play a causal role in the development of heart failure. However, whether changes in CaMKII are causal or secondary to the development of cardiac diseases remains to be established. Nonetheless, the findings clearly indicate that regulatory changes in CaMKII expression occur in association with cardiac pathology.

\section{B. EFFECTS OF CAMKII $\delta_{\mathrm{C}}$ OVEREXPRESSION ON CA ${ }^{2+}$ HANDLING IN TRANSGENIC MICE}

As was discussed, CaMKII plays important roles in $\mathrm{Ca}^{2+}$ cycling and E-C coupling in cardiomyocytes in vitro, although the extent to which this can occur in vivo has not been addressed. Accordingly, our laboratory generated TG mice that expressed the cytoplasmic CaMKII $\delta_{\mathrm{C}}$ isoform in the heart and examined phosphorylation of $\mathrm{Ca}^{2+}$ regulatory proteins and concomitant changes in cellular $\mathrm{Ca}^{2+}$ regulation. These mice developed a dilated cardiomyopathy characterized by a significant decrease in cardiac function and premature death (Zhang et al., 2003). The time course for development of functional impairment and extent of lethality were related to the gene dosage for CaMKII expression in several TG founder lines (Zhang et al., 2003). Further studies exploring the mechanisms by which CaMKII expression induced these phenotypic changes examined changes in the phosphorylation state of $\mathrm{Ca}^{2+}$ regulatory proteins in cardiac homogenates and alterations in $\mathrm{Ca}^{2+}$-handling properties in adult cardiomyocytes isolated from the TG mice (Maier et al., 2003; Zhang et al., 2003).

We hypothesized that the initial effects of $\mathrm{CaMKII} \delta_{\mathrm{C}}$ on $\mathrm{Ca}^{2+}$ handling would be adaptive responses that serve to increase contractile function. Our finding of a rapid increase in CaMKII activation in response to pressure overload induced by TAC (Zhang et al., 2003) is consistent with CaMKII serving such an adaptive role. Enhanced PLB phosphorylation, which would be expected to increase $\mathrm{SR} \mathrm{Ca}{ }^{2+}$ transport and SR $\mathrm{Ca}^{2+}$ stores, was evidenced by the increased PLB phosphorylation at Thr17 site in CaMKII $\delta_{\mathrm{C}}$ TG mouse hearts vs. wild type (WT) (Zhang et al., 2003). We also demonstrated that RyR2 phosphorylation was increased in CaMKII $\delta_{\mathrm{C}}$ TG vs. WT mouse hearts. This was established both by back phosphorylation (Zhang et al., 2003) and through use of a phospho-specific antibody for Ser2809 that showed a significant increase in phospho-RyR2 in TG vs. WT hearts (T. Zhang and J.H. Brown, unpublished data). 
As discussed earlier, hyperphosphorylation of RyR2 by PKA is suggested to play a major role in the etiology of heart failure (Marx et al., 2000). We hypothesized that this also might occur with CaMKII-mediated changes in RyR2 phosphorylation and function. The functional consequences of RyR2 phosphorylation were assessed in myocytes isolated from the CaMKII $\delta_{\mathrm{C}}$ TG mice (Maier et al., 2003). Diastolic $\mathrm{Ca}^{2+}$ spark frequency was increased in TG myocytes and the sparks were of increased width and prolonged duration. The overall diastolic $\mathrm{SR} \mathrm{Ca}^{2+}$ leakage was 4.3-fold higher in TG vs. WT cardiomyocytes. Importantly, SR $\mathrm{Ca}^{2+}$ release during twitch (relative to the total $\mathrm{SR}^{2}{ }^{2+}$ pool) was found to be increased in TG vs. WT, despite lower SR $\mathrm{Ca}^{2+}$ load and diastolic intracellular $\mathrm{Ca}^{2+}$. Another important finding was that RyR2 phosphorylation and $\mathrm{Ca}^{2+}$ spark frequency were increased at early stages, prior to development of failure (assessed by echocardiography), in CaMKII $\delta_{\mathrm{C}} \mathrm{TG}$ mouse hearts. We also reported that the increased $\mathrm{Ca}^{2+}$ spark frequency in isolated TG myocytes was normalized by acute CaMKII inhibition and that CaMKII $\delta$ was associated with the RyR2 in immunoprecipitation studies (Zhang et al., 2003). Taken together, these data demonstrate that CaMKII mediates RyR2 phosphorylation in vivo, that this results in increases in $\mathrm{SR} \mathrm{Ca}^{2+}$ spark frequency, and that these precede (and could therefore be causal in) the development of failure (Zhang et al., 2003).

Other changes in $\mathrm{Ca}^{2+}$ handling were observed in CaMKII $\delta_{\mathrm{C}}$ TG mice, including direct effects of overexpressed $\mathrm{CaMKII} \delta_{\mathrm{C}}$ on peak $I_{\mathrm{Ca}}$ and FDAR (Maier et al., 2003). Peak $I_{\mathrm{Ca}}$ was slightly increased in TG vs. WT and was acutely reversed by CaMKII inhibition. However, CaMKII-dependent $I_{\mathrm{Ca}}$ facilitation still was present in TG mice, suggesting that CaMKII activation in the TG mouse hearts was not sufficient to saturate $I_{\mathrm{Ca}}$ facilitation. FDAR was only slightly (albeit significantly) enhanced in TG mice (Maier et al., 2003), implying that CaMKII is involved in FDAR but that endogenous CaMKII levels in WT mice may not be rate limiting. Changes in SERCA (decreased) and NCX (increased) expression and function observed in CaMKII TG mice are presumably secondary to heart failure development in these mice, since there is no evidence that CaMKII can directly downregulate SERCA2a or upregulate NCX function. Similar changes in SERCA2a and NCX function are seen in numerous heart failure models.

\section{VIII. $\mathrm{Ca}^{2+}$ and Apoptosis}

\section{A. IMPORTANCE OF APOPTOSIS IN ISCHEMIA/REPERFUSION INJURY AND THE DEVELOPMENT OF HEART FAILURE}

Apoptosis or programmed cell death plays an important role in development and has been implicated in diseases, including cancer, autoimmune diseases, and 
degenerative disorders. Apoptosis is widely recognized as a factor contributing to heart failure. Over the last decade, it has been shown that apoptotic cell death is associated with myocardial infarction, ischemia/reperfusion, and cardiomyopathy (Gottleib et al., 1994; Olivetti et al., 1997). The development of apoptosis is highly regulated in a step-by-step fashion by many signaling events, providing the potential for multiple sites of therapeutic intervention. There are two relatively distinct pathways in apoptosis: the intrinsic (mitochondrial) pathway and the extrinsic (death receptor) pathway. Both eventually converge on caspase-3, a key component of the apoptotic machinery.

In response to ischemia/reperfusion, both apoptosis and necrosis are observed and the contribution of each to cardiomyocyte cell death is controversial. However, it has been reported that caspase inhibitors, which block apoptosis, protect against ischemia/reperfusion damage (Yaoita et al., 1998). A mitochondrial permeability transition pore inhibitor has been shown to be protective against ischemia/reperfusion in ventricular myocytes and isolated hearts (Griffiths and Halestrap, 1993; Murata et al., 2001). These findings implicate apoptosis in the pathological response to ischemia/reperfusion. Interestingly, while the border zone of infarction shows apoptotic cell death, infarct zones in the myocardium show necrosis, raising the possibility that cell death starts by way of the more-tidy apoptotic pathway but ultimately regresses to one with necrotic features (Yaoita et al., 1998).

Myocyte loss by apoptosis is recognized as a major contributing factor in the transition from compensated (adaptive) hypertrophy to heart failure (maladaptation). Conditional KO of gp130, a receptor through which cytokines regulate cardiomyocyte survival, has been reported to result in massive induction of myocyte apoptosis and rapid onset of dilated cardiomyopathy in response to aortic banding (Hirota et al., 1999). Direct induction of apoptosis by conditional caspase activation also induces heart failure in transgenic mice (Wencker et al., 2003). Activation of the $\mathrm{G} \alpha \mathrm{q}$ signaling pathway, when sustained or exacerbated, induces heart failure with apoptosis (Adams et al., 1998,2000). The peripartum cardiomyopathy seen in $\mathrm{G} \alpha \mathrm{q}$ transgenic mice is markedly attenuated by caspase inhibition (Hayakawa et al., 2003).

\section{B. $\mathrm{CA}^{2+}$, PERMEABILITY TRANSITION PORE, AND CARDIOPROTECTION}

Many experimental models of cardiomyocyte apoptosis - including ischemia/reperfusion and sustained $\mathrm{G} \alpha \mathrm{q}$ signaling — are associated with mitochondrial changes due to the opening of the mitochondrial permeability transition pore (PT pore) (Halestrap et al., 1997; Adams et al., 2000). The PT pore is considered to be a megachannel with permeability to ions and solutes up to $\approx$ 1500 daltons. Although not all of the molecules comprising the PT pore are 
known, the adenine nucleotide translocator (ANT) and voltage-dependent anion channel (VDAC) are among them. Long-lasting PT pore opening has been reported to dissipate the mitochondrial membrane potential and decrease ATP production (Kroemer and Reed, 2000). Cytochrome $c$ is released through the PT pore and acts, along with other cytosolic factors, to promote caspase-9 activation. Subsequent caspase-3 activation mediates DNA cleavage into nucleosomal fragments. PT pore opening has been reported to be regulated by several factors. Increases in $\mathrm{Ca}^{2+}$, reactive oxygen species (ROS), and proapoptotic Bcl-2 family proteins (e.g., Bad, Bax, tBid) induce PT pore opening, while antiapoptotic $\mathrm{Bcl}-2$ family proteins such as Bcl-2 and Bcl-xl inhibit the PT pore (for a review, see Kroemer and Reed, 2000).

The involvement of $\mathrm{Ca}^{2+}$ in regulating mitochondrial function has been appreciated for many years. Mitochondria take up cytosolic $\mathrm{Ca}^{2+}$ via a $\mathrm{Ca}^{2+}$ uniporter. Recent studies show that mitochondrial $\mathrm{Ca}^{2+}$ changes in a beat-to-beat manner in cardiomyocytes (Robert et al., 2001). Furthermore, a close relationship between the SR and mitochondria in cardiomyocytes is illustrated by studies demonstrating that $\mathrm{Ca}^{2+}$ derived from SR (via $\mathrm{Ca}^{2+}$-induced $\mathrm{Ca}^{2+}$ release mechanism) is efficiently transmitted to the mitochondria (Szalai et al., 2000). A more-recent focus has been on the role of mitochondrial $\mathrm{Ca}^{2+}$ in PT pore opening (Crompton, 1999; Murata et al., 2001). Experiments using isolated mitochondria or permeabilized cells clearly demonstrate that high concentration of $\mathrm{Ca}^{2+}$ can induce PT pore opening (Crompton, 1999). Our unpublished observations demonstrate that ionomycin, a $\mathrm{Ca}^{2+}$ ionophore, induces PT pore opening (assessed by loss of mitochondrial membrane potential) and induces DNA laddering in neonatal rat ventricular myocytes. We also have observed that cytosolic $\mathrm{Ca}^{2+}$ dysregulation and resultant $\mathrm{Ca}^{2+}$ overloading directly induce PT pore opening and apoptosis in cardiomyocytes subject to sustained stimulation of $\mathrm{G} \alpha \mathrm{q}$ signaling pathways, while chelation of $\mathrm{Ca}^{2+}$ with EGTA (ethylene glycol-bis(betaamino ethyl ether)-N, N, N', $\mathrm{N}^{\prime}$-tetraacetic acid) inhibits these responses ( $\mathrm{S}$. Miyamoto and J. H. Brown, unpublished data).

Another mitochondrial channel that may be involved in regulating mitochondrial $\mathrm{Ca}^{2+}$ concentration and PT pore function is the mitochondrial ATPsensitive potassium channel $\left(\right.$ mitoK $\left._{\mathrm{ATP}}\right)$. $\mathrm{MitoK}_{\mathrm{ATP}}$ has attracted considerable interest since Liu and coworkers (1998) reported that diazoxide selectively opens these channels and confers cardiac protection against subsequent ischemia. Although not all of the operative cardioprotective mechanisms have been elucidated, it has been shown that diazoxide treatment inhibits mitochondrial $\mathrm{Ca}^{2+}$ overloading (Murata et al., 2001). Three mechanisms by which mitoK ${ }_{\text {ATP }}$ channel opening could lead to protection have been suggested. One is that $\mathrm{K}^{+}$ influx reduces the driving force for $\mathrm{Ca}^{2+}$ by mitochondrial membrane depolarization (Holmuhamedov et al., 1999). Second, opening the mitoK $\mathrm{K}_{\mathrm{ATP}}$ channel induces moderate production of ROS, which contributes to cardioprotection by 
stimulating protein kinases, in particular, PKC (Forbes et al., 2001). Third, it has been proposed that treatment with diazoxide results in release of mitochondrial $\mathrm{Ca}^{2+}$ by inducing flickering PT pore opening (low-conductance state) (Katoh et al., 2002).

Recently, another $\mathrm{Ca}^{2+}$-dependent pathway has been suggested to be responsible for cytochrome $c$ release during ischemia/reperfusion (M. Chen $e t$ al., 2001,2002). Calpain, a $\mathrm{Ca}^{2+}$-dependent cysteine protease, is activated by the rapid influx of $\mathrm{Ca}^{2+}$ stimulated by reperfusion and cleaves Bid, a proapoptotic BH3-only Bcl-2 family member. The product of the cleavage, tBid, induces mitochondrial dysfunction. Calpain has been recognized as an important mediator of necrotic cell death through proteolysis; thus, these results suggest possible cross-talk between apoptotic and necrotic pathways.

\section{CAMK INVOLVEMENT IN APOPTOSIS}

There is limited but compelling evidence that CaMKII can mediate signal transduction in apoptosis. Selective inhibitors of CaMKII significantly inhibit apoptotic responses induced by tumor necrosis factor alpha $(\mathrm{TNF} \alpha)$, ultraviolet irradiation, and the natural toxin microcystin (Wright et al., 1997; Fladmark et al., 2002). In addition, overexpression of active forms of CaMKII can induce apoptosis (Fladmark et al., 2002). CaMKII has been shown to regulate expression and phosphorylation of c-FLIP (cellular Fas-associated death domain-like interleukin- $\beta$-converting enzyme inhibitory protein), thus modulating Fasmediated signaling (Yang et al., 2003). Our recent collaborative studies demonstrated that apoptosis induced by $\beta 1$-adrenergic receptor stimulation in adult mouse cardiomyocytes occurs through activation of CaMKII rather than PKA (Zhu et al., 2003). We reported that CaMKII inhibition protected cardiomyocytes against apoptosis and that expression of the cytoplasmic $\mathrm{CaMKII} \delta_{\mathrm{C}}$ (but not the nuclear CaMKII $\delta_{\mathrm{B}}$ ) enhanced the apoptotic response (Zhu et al., 2003). Further investigation is needed to elucidate the downstream targets of CaMKII in apoptotic signaling pathways. However, it is intriguing to consider that chronic activation or increased expression of $\mathrm{CaMKII} \delta_{\mathrm{C}}$ not only contributes to the altered $\mathrm{Ca}^{2+}$ handling and contractile dysfunction associated with heart failure but also serves as a mediator of apoptotic loss of cardiomyocytes.

\section{Summary}

Changes in intracellular $\mathrm{Ca}^{2+}$ underlie multiple cardiomyocyte responses and are critical to the fundamental function of the heart as a pump. Studies carried out over the past decade demonstrate that CaMK is a ubiquitous transducer of $\mathrm{Ca}^{2+}$ signals. Thus, the possible role of CaMKII in cardiac function has generated considerable interest. The discovery of distinct CaMKII $\delta$ splice 
variants that localize to the cytoplasm vs. the nucleus suggests that there could be precise spatial regulation of CaMKII activation and function in cardiomyocytes. Whether the cardiac CaMKII isoforms are differentially regulated by $\mathrm{Ca}^{2+}$ mobilized in response to particular stimuli or arising from distinct sources remains to be determined. Data presented herein suggest that the isoforms may play distinct roles in transcriptional regulation, $\mathrm{Ca}^{2+}$ homeostasis, and control of apoptosis. Information on dynamic changes in CaMKII isoform activation during the cardiac contraction cycle and on more-chronic changes in CaMKII activation and expression in adaptive and maladaptive phases of cardiac diseases will be necessary to gain further insight into physiological and pathological functions of CaMKII. It is abundantly clear, however, that there are multiple avenues for manipulating cardiac $\mathrm{Ca}^{2+} / \mathrm{CaMKII}$ signaling pathways that hold considerable therapeutic potential.

\section{ACKNOWLEDGMENTS}

The authors would like to thank Dr. Howard Schulman (Stanford University) for providing CaMKII $\delta_{\mathrm{B}}$ and $\delta_{\mathrm{C}} \mathrm{cDNA}$ and Dr. Donald Bers (Loyola University) for many helpful discussions. This work was supported by National Institutes of Health grant HL-46345 and HL-28143 (to Dr. Joan Heller Brown). Dr. Tong Zhang is supported by an American Heart Association postdoctoral fellowship.

\section{REFERENCES}

Adams JW, Sakata Y, Davis MG, Sah VP, Wang Y, Liggett SB, Chien KR, Brown JH, Dorn GW 1998 Enhanced $\mathrm{G} \alpha_{\mathrm{q}}$ signaling: a common pathway mediates cardiac hypertrophy and apoptotic heart failure. Proc Natl Acad Sci USA 95:10140-10145

Adams JW, Pagel AL, Means CK, Oksenberg D, Armstrong RC, Brown JH 2000 Cardiomyocyte apoptosis induced by $\mathrm{G} \alpha \mathrm{q}$ signaling is mediated by permeability transition pore formation and activation of the mitochondrial death pathway. Circ Res 87:1180-1187

Anderson ME, Braun AP, Schulman H, Premack BA 1994 Multifunctional $\mathrm{Ca}^{2+} /$ calmodulindependent protein kinase mediates $\mathrm{Ca}^{2+}$-induced enhancement of the $\mathrm{L}$-type $\mathrm{Ca}^{2+}$ current in rabbit ventricular myocytes. Circ Res 75:854-861

Anderson ME, Braun AP, Wu Y, Lu T, Schulman H, Sung RJ 1998 KN-93, an inhibitor of multifunctional $\mathrm{Ca}^{2+} /$ calmodulin-dependent protein kinase, decreases early afterdepolarizations in rabbit heart. J Pharmacol Exp Ther 287:996-1006

Aoki H, Sadoshima J, Izumo S 2000 Myosin light chain kinase mediates sarcomere organization during cardiac hypertrophy in vitro. Nature Med 6:183-188

Baltas LG, Karczewski P, Krause E-G 1995 The cardiac sarcoplasmic reticulum phospholamban kinase is a distinct $\delta$-CaM kinase isozyme. FEBS Lett 373:71-75

Bassani RA, Mattiazzi A, Bers DM 1995 CaMKII is responsible for activity-dependent acceleration of relaxation in rat ventricular myocytes. Am J Physiol 268:H703-H712

Benitah JP, Gomez AM, Fauconnier J, Kerfant BG, Perrier E, Vassort G, Richard S 2002 Voltage-gated $\mathrm{Ca}^{2+}$ currents in the human pathophysiologic heart: a review. Basic Res Cardiol 97(suppl 1):I11-I18

Berridge MJ 1997 The AM and FM of calcium signalling. Nature 386:759-760 
Bers DM 2002 Cardiac excitation-contraction coupling. Nature 415:198-205

Bers DM, Perez-Reyes E $1999 \mathrm{Ca}^{2+}$ channels in cardiac myocytes: structure and function in $\mathrm{Ca}^{2+}$ influx and intracellular $\mathrm{Ca}^{2+}$ release. Cardiovasc Res 42:339-360

Blaeser F, Ho N, Prywes R, Chatila T $2000 \mathrm{Ca}^{2+}$-dependent gene expression mediated by MEF2 transcription factors. J Biol Chem 275:197-209

Boknik P, Heinroth-Hoffman I, Kirchhefer U, Knapp J, Linck B, Luss H, Muller T, Schmitz W, Brodde O-E, Neumann J 2001 Enhanced protein phosphorylation in hypertensive hypertrophy. Cardiovasc Res 51:717-728

Braun AP, Schulman H 1995 The multifunctional calcium/calmodulin-dependent protein kinase: from form to function. Annu Rev Physiol 57:417-445

Chen M, He H, Zhan S, Krajewski S, Reed JC, Gottlieb RA 2001 Bid is cleaved by calpain to an active fragment in vitro and during myocardial ischemia/reperfusion. J Biol Chem 276: 30724-30728

Chen M, Won DJ, Krajewski S, Gottlieb RA 2002 Calpain and mitochondria in ischemia/ reperfusion injury. J Biol Chem 277:29181-29186

Chen X, Piacentino V III, Furukawa S, Goldman B, Margulies KB, Houser SR 2002 L-type $\mathrm{Ca}^{2+}$ channel density and regulation are altered in failing human ventricular myocytes and recover after support with mechanical assist devices. Circ Res 91:517-524

Chien KR, Ross J Jr, Hoshijima M 2003 Calcium and heart failure: the cycle game. Nature Med 9:508-509

Chu G, Lester JW, Young KB, Luo W, Zhai J, Kranias EG 2000 A single site (Ser16) phosphorylation in phospholamban is sufficient in mediating its maximal cardiac responses to $\beta$-agonists. J Biol Chem 275:38938-38943

Colomer JM, Means AR 2000 Chronic elevation of calmodulin in the ventricles of transgenic mice increases the autonomous activity of calmodulin-dependent protein kinase II, which regulates atrial natriuretic factor gene expression. Mol Endocrinol 14:1125-1136

Colomer JM, Mao L, Rockman HA, Means AR 2003 Pressure overload selectively up-regulates $\mathrm{Ca}^{2+} /$ calmodulin-dependent protein kinase II in vivo. Mol Endocrinol 17:183-192

Crompton M 1999 The mitochondrial permeability transition pore and its role in cell death. Biochem J 341:233-249

Currie S, Smith GL 1999 Calcium/calmodulin-dependent protein kinase II activity is increased in sarcoplasmic reticulum from coronary artery ligated rabbit hearts. FEBS Lett 459:244-248

Davis FJ, Gupta M, Camoretti-Mercado B, Schwartz RJ, Gupta MP 2003 Calcium/calmodulindependent protein kinase activates serum response factor transcription activity by its dissociation from histone deacetylase, HDAC4: implications in cardiac muscle gene regulation during hypertrophy. J Biol Chem 278:20047-20058

Del Monte F, Harding SE, Dec GW, Gwathmey JK, Hajjar RJ 2002 Targeting phospholamban by gene transfer in human heart failure. Circulation 105:904-907

DeSantiago J, Maier LS, Bers DM 2002 Frequency-dependent acceleration of relaxation in the heart depends on CaMKII, but not phospholamban. J Mol Cell Cardiol 34:975-984

De Windt LJ, Lim HW, Taigen T, Wencker D, Condorelli G, Dorn GW, Kitsis RN, Molkentin JD 2000 Calcineurin-mediated hypertrophy protects cardiomyocytes from apoptosis in vitro and in vivo: an apoptosis-independent model of dilated heart failure. Circ Res 86:255-263

De Windt LJ, Lim HW, Bueno OF, Liang Q, Delling U, Braz JC, Glascock BJ, Kimball TF, del Monte F, Hajjar RJ, Molkentin JD 2001 Targeted inhibition of calcineurin attenuates cardiac hypertrophy in vivo. Proc Natl Acad Sci USA 98:3322-3327

Doi M, Yano M, Kobayashi S, Kohno M, Tokuhisa T, Okuda S, Suetsugu M, Hisamatsu Y, Ohkusa T, Kohno M, Matsuzaki M 2002 Propranolol prevents the development of heart failure by restoring FKBP12.6-mediated stabilization of ryanodine receptor. Circulation 105:1374-1379 
Dolmetsch RE, Lewis RS, Goodnow CC, Healy JI 1997 Differential activation of transcription factors induced by $\mathrm{Ca}^{2+}$ response amplitude and duration. Nature 386:855-858

Dzhura I, Wu Y, Colbran RJ, Balser JR, Anderson ME 2000 Calmodulin kinase determines calcium-dependent facilitation of L-type calcium channels. Nature Cell Biol 2:173-177

Edman CF, Schulman H 1994 Identification and characterization of $\delta_{\mathrm{B}}-\mathrm{CaM}$ kinase and $\delta_{\mathrm{C}}-\mathrm{CaM}$ kinase from rat heart, two new multifunctional $\mathrm{Ca}^{2+} /$ calmodulin-dependent protein kinase isoforms. Biochim Biophys Acta 1221:89-101

Fladmark KE, Brustugun OT, Mellgren G, Krakstad C, Boe R, Vintermyr OK, Schulman H, Doskeland SO $2002 \mathrm{Ca}^{2+} /$ calmodulin-dependent protein kinase II is required for microcystin-induced apoptosis. J Biol Chem 277:2804-2811

Forbes RA, Steenbergen C, Murphy E 2001 Diazoxide-induced cardioprotection requires signaling through a redox-sensitive mechanism. Circ Res 88:802-809

Frey N, McKinsey TA, Olson EN 2000 Decoding calcium signals involved in cardiac growth and function. Nature Med 6:1221-1227

Gomez AM, Guatimosim S, Dilly KW, Vassort G, Lederer WJ 2001 Heart failure after myocardial infarction: altered excitation-contraction coupling. Circulation 104:688-693

Gottleib RA, Burleson KO, Kloner RA, Babior BM, Engler RL 1994 Reperfusion injury induces apoptosis in rabbit cardiomyocytes. J Clin Invest 94:1621-1628

Griffiths EJ, Halestrap AP 1993 Protection by cyclosporin A of ischema/reperfusion-induced damage in isolated rat hearts. J Mol Cell Cardiol 25:1461-1469

Gruver CL, DeMayo F, Goldstein MA, Means AR 1993 Targeted developmental overexpression of calmodulin induces proliferative and hypertrophic growth of cardiomyocytes in transgenic mice. Endocrinology 133:376-388

Hagemann D, Kuschel M, Kuramochi T, Zhu W, Cheng H, Xiao RP 2000 Frequency-encoding Thr17 phospholamban phosphorylation is independent of Ser16 phosphorylation in cardiac myocytes. J Biol Chem 275:22532-22536

Hagemann D, Bohlender J, Hoch B, Krause EG, Karczewski P 2001 Expression of $\mathrm{Ca}^{2+}$ / calmodulin-dependent protein kinase II $\delta$-subunit isoforms in rats with hypertensive cardiac hypertrophy. Mol Cell Biochem 220:69-76

Hain J, Onoue H, Mayrleitner M, Fleischer S, Schindler H 1995 Phosphorylation modulates the function of the calcium release channel of sarcoplasmic reticulum from cardiac muscle. J Biol Chem 270:2074-2081

Halestrap AP, Connern CP, Griffiths EJ, Kerr PM 1997 Cyclosporin A binding to mitochondrial cyclophilin inhibits the permeability transition pore and protects hearts from ischaemia/ reperfusion injury. Mol Cell Biochem 174:167-172

Hardingham GE, Bading H 1998 Nuclear calcium: a key regulator of gene expression. Biometals 11:345-358

Hayakawa Y, Chandra M, Miao W, Shirani J, Brown JH, Dorn GW II, Armstrong RC, Kitsis RN 2003 Inhibition of cardiac myocyte apoptosis improves cardiac function and abolishes mortality in the peripartum cariomyopathy of G $\alpha$ q transgenic mice. Circulation, 108:30363041

He J, Conklin MW, Foell JD, Wolff MR, Haworth RA, Coronado R, Kamp TJ 2001 Reduction in density of transverse tubules and L-type $\mathrm{Ca}^{2+}$ channels in canine tachycardia-induced heart failure. Cardiovasc Res 49:298-307

Heist EK, Schulman H 1998 The role of $\mathrm{Ca}^{2+}$ /calmodulin-dependent protein kinases within the nucleus. Cell Calcium 23:103-114

Hilgemann DW, Ball R 1996 Regulation of cardiac $\mathrm{Na}^{+}, \mathrm{Ca}^{2+}$ exchange and $\mathrm{K}_{\text {ATP }}$ potassium channels by PIP $_{2}$. Science 273:956-959 
Hirota H, Chen J, Betz UAK, Rajewsky K, Gu Y, Ross J Jr, Muller W, Chien KR 1999 Loss of a gp130 cardiac muscle cell survival pathway is a critical event in the onset of heart failure during biomechanical stress. Cell 97:189-198

Ho N, Gullberg M, Chatila T 1996 Activation protein 1-dependent transcriptional activation of interleukin 2 gene by $\mathrm{Ca}^{2+} /$ calmodulin kinase type IV/Gr. J Exp Med 184:101-112

Hoch B, Meyer R, Hetzer R, Krause E-G, Karczewski P 1999 Identification and expression of $\delta$-isoforms of the multifunctional $\mathrm{Ca}^{2+} /$ calmodulin dependent protein kinase in failing and nonfailing human myocardium. Circ Res 84:713-721

Holmuhamedov EL, Wang L, Terzic A 1999 ATP-sensitive $\mathrm{K}^{+}$channel openers prevent $\mathrm{Ca}^{2+}$ overload in rat cardiac mitochondria. J Physiol 519(pt 2):347-360

Houser SR, Piacentino V III, Weisser J 2000 Abnormalities of calcium cycling in the hypertrophied and failing heart. J Mol Cell Cardiol 32:1595-1607

Huang B, Wang S, Qin D, Boutjdir M, El-Sherif N 1999 Diminished basal phosphorylation level of phospholamban in the postinfarction remodeled rat ventricle. Circ Res 85:848-855

Hudmon A, Schulman H 2002 Structure-function of the multifunctional $\mathrm{Ca}^{2+} /$ calmodulin-dependent protein kinase II. Biochem J 364:593-611

Iwamoto T, Pan Y, Wakabayashi S, Imagawa T, Yamanaka HI, Shigekawa M 1996 Phosphorylation-dependent regulation of cardiac $\mathrm{Na}^{+} / \mathrm{Ca}^{2+}$ exchanger via protein kinase C. J Biol Chem 271:13609-13615

Ji Y, Li B, Reed TD, Lorenz JN, Kaetzel MA, Dedman JR 2003 Targeted inhibition of $\mathrm{Ca}^{2+} /$ calmodulin-dependent protein kinase II in cardiac longitudinal sarcoplasmic reticulum results in decreased phospholamban phosphorylation at threonine 17. J Biol Chem 278: 25063-25071

Kato T, Sano M, Miyoshi S, Sato T, Hakuno D, Ishida H, Kinoshita-Nakazawa H, Fukuda K, Ogawa S 2000 Calmodulin kinases II and IV and calcineurin are involved in leukemia inhibitory factor-induced cardiac hypertrophy in rats. Circ Res 87:937-945

Katoh H, Nishigaki N, Hayashi H 2002 Diazoxide opens the mitochondrial permeability transition pore and alters $\mathrm{Ca}^{2+}$ transients in rat ventricular myocytes. Circulation 105:2666-2671

Kirchhefer U, Schmitz W, Scholz H, Neumann J 1999 Activity of cAMP-dependent protein kinase and $\mathrm{Ca}^{2+}$ /calmodulin-dependent protein kinase in failing and nonfailing human hearts. Cardiovasc Res 42:254-261

Kolodziejczyk SM, Wang L, Balazsi K, DeRepentigny Y, Kothary R, Megeney LA 1999 MEF2 is upregulated during cardiac hypertrophy and is required for normal post-natal growth of the myocardium. Curr Biol 9:1203-1206

Kroemer G, Reed JC 2000 Mitochondrial control of cell death. Nature Med 6:513-519

Le Peuch CJ, Haiech J, Demaille JG 1979 Concerted regulation of cardiac sarcoplasmic reticulum calcium transport by cyclic adenosine monophosphate dependent and calcium-calmodulindependent phosphorylations. Biochemistry 18:5150-5157

Lee JC, Edelman AM 1994 A protein activator of $\mathrm{Ca}^{2+}$ calmodulin-dependent protein kinase Ia. J Biol Chem 269:2158-2164

Li L, Satoh H, Ginsburg KS, Bers DM 1997 The effect of $\mathrm{Ca}^{2+}$-calmodulin-dependent protein kinase II on cardiac excitation-contraction coupling in ferret ventricular myocytes. J Physiol 501:17-31

Liu Y, Sato T, O'Rourke B, Marban E 1998 Mitochondrial ATP-dependent potassium channels: novel effectors of cardioprotection? Circulation 97:2463-2469

Lokuta AJ, Rogers TB, Lederer WJ, Valdivia HH 1995 Modulation of cardiac ryanodine receptors of swine and rabbit by a phosphorylation-dephosphorylation mechanism. J Physiol 487(pt 3):609-622 
Lu J, McKinsey TA, Nicol RL, Olson EN 2000 Signal-dependent activation of the MEF2 transcription factor by dissociation from histone deacetylases. Proc Natl Acad Sci USA 97:4070-4075

Luo W, Chu G, Sato Y, Zhou Z, Kadambi VJ, Kranias EG 1998 Transgenic approaches to define the functional role of dual site phospholamban phosphorylation. J Biol Chem 273:4734-4739

Maier LS, Zhang T, Chen L, DeSantiago J, Brown JH, Bers DM 2003 Transgenic CaMKII $\delta_{\mathrm{C}}$ overexpression uniquely alters cardiac myocyte $\mathrm{Ca}^{2+}$ handling: reduced $\mathrm{SR} \mathrm{Ca}^{2+}$ load and activated $\mathrm{SR} \mathrm{Ca}^{2+}$ release. Circ Res 92:904-911

Malviya AN, Rogue PJ 1998 "Tell me where is calcium bred": clarifying the roles of nuclear calcium. Cell 92:17-23

Marks AR 2000 Cardiac intracellular calcium release channels: role in heart failure. Circ Res $87: 8-11$

Marx SO, Reiken S, Hisamatsu Y, Jayaraman T, Burkhoff D, Rosemblit N, Marks AR 2000 PKA phosphorylation dissociates FKBP12.6 from the calcium release channel (ryanodine receptor): defective regulation in failing hearts. Cell 101:365-376

Matthews RP, Guthrie CR, Wailes LM, Zhao X, Means AR, McKnight GS 1994 Calcium/ calmodulin-dependent protein kinase types II and IV differentially regulate CREB-dependent gene expression. Mol Cell Biol 14:6107-6116

Mayer P, Mohlig M, Idlibe D, Pfeiffer A 1995 Novel and uncommon isoforms of the calcium sensing enzyme calcium/calmodulin dependent protein kinase II in heart tissue. Basic Res Cardiol 90:372-379

Meyer S, Kohler NG, Joly A 1997 Cyclosporine A is an uncompetitive inhibitor of proteasome activity and prevents NF-kappaB activation. FEBS Lett 413:354-358

Meyers MB, Pickel VM, Sheu SS, Sharma VK, Scotto KW, Fishman GI 1995 Association of sorcin with the cardiac ryanodine receptor. J Biol Chem 270:26411-26418

Mishra S, Sabbah HN, Jain JC, Gupta RC 2003 Reduced $\mathrm{Ca}^{2+}$-calmodulin-dependent protein kinase activity and expression in LV myocardium of dogs with heart failure. Am J Physiol 284:H876-H883

Misra RP, Bonni A, Miranti CK, Rivera VM, Sheng M, Greenberg ME 1994 L-type voltagesensitive calcium channel activation stimulates gene expression by a serum response factordependent pathway. J Biol Chem 269:25483-25493

Molkentin JD 2000 Calcineurin and beyond: cardiac hypertrophic signaling. Circ Res 87:731-738

Molkentin JD, Lu J-R, Antos CL, Markham B, Richardson J, Robbins J, Grant SR, Olson EN 1998 A calcineurin-dependent transcriptional pathway for cardiac hypertrophy. Cell 93:215228

Movsesian MA, Karimi M, Green K, Jones LR $1994 \mathrm{Ca}^{2+}$-transporting ATPase, phospholamban, and calsequestrin levels in nonfailing and failing human myocardium. Circulation 90:653657

Mundina-Weilenmann C, Vittone L, Ortale M, de Cingolani GC, Mattiazzi A 1996 Immunodetection of phosphorylation sites gives new insights into the mechanisms underlying phospholamban phosphorylation in the intact heart. J Biol Chem 271:33561-33567

Murata M, Akao M, O'Rourke B, Marban E 2001 Mitochondrial ATP-sensitive potassium channels attenuate matrix $\mathrm{Ca}^{2+}$ overload during simulated ischemia and reperfusion: possible mechanism of cardioprotection. Circ Res 89:891-898

Netticadan T, Temsah RM, Kawabata K, Dhalla NS 2000 Sarcoplasmic reticulum $\mathrm{Ca}^{2+}$ / calmodulin-dependent protein kinase is altered in heart failure. Circ Res 86:596-605

Nuss HB, Houser SR 1992 Sodium-calcium exchange-mediated contractions in feline ventricular myocytes. Am J Physiol 263:H1161-H1169 
Odermatt A, Kurzydlowski K, MacLennan DH 1996 The vmax of the $\mathrm{Ca}^{2+}$-ATPase of cardiac sarcoplasmic reticulum (SERCA2a) is not altered by $\mathrm{Ca}^{2+} /$ calmodulin-dependent phosphorylation or by interaction with phospholamban. J Biol Chem 271:14206-14213

Olivetti G, Abbi R, Quaini F, Kajstura J, Cheng W, Nitahara JA, Di Loreto C, Beltrami CA, Krajewski S, Reed JC, Anversa P 1997 Apoptosis in the failing human heart. N Engl J Med 336:1131-1141

Olson EN, Williams RS 2000 Calcineurin signaling and muscle remodeling. Cell 101:689-692

Passier R, Zeng h, Frey N, Naya FJ, Nicol RL, McKinsey TA, Overbeek PA, Richardson JA, Grant SR, Olson EN 2000 CaM kinase signaling induces cardiac hypertrophy and activates the MEF2 transcription factor in vivo. J Clin Invest 105:1395-1406

Perchenet L, Hinde AK, Patel KC, Hancox JC, Levi AJ 2000 Stimulation of $\mathrm{Na}^{+} / \mathrm{Ca}^{2+}$ exchange by the $\beta$-adrenergic/protein kinase A pathway in guinea-pig ventricular myocytes at 37 degrees C. Pflugers Arch 439:822-828

Ramirez MT, Zhao X, Schulman H, Brown JH 1997 The nuclear $\delta_{\mathrm{B}}$ isoform of $\mathrm{Ca}^{2+} /$ calmodulindependent protein kinase II regulates atrial natriuretic factor gene expression in ventricular myocytes. J Biol Chem 272:31203-31208

Reddy LG, Jones LR, Pace RC, Stokes DL 1996 Purified, reconstituted cardiac $\mathrm{Ca}^{2+}$-ATPase is regulated by phospholamban but not by direct phosphorylation with $\mathrm{Ca}^{2+} /$ calmodulindependent protein kinase. J Biol Chem 271:14964-14970

Reiken S, Gaburjakova M, Guatimosim S, Gomez AM, D'Armiento J, Burkhoff D, Wang J, Vassort G, Lederer WJ, Marks AR 2003a Protein kinase A phosphorylation of the cardiac calcium release channel (ryanodine receptor) in normal and failing hearts. Role of phosphatases and response to isoproterenol. J Biol Chem 278:444-453

Reiken S, Wehrens XH, Vest JA, Barbone A, Klotz S, Mancini D, Burkhoff D, Marks AR 2003b $\beta$-blockers restore calcium release channel function and improve cardiac muscle performance in human heart failure. Circulation 107:2459-2466

Robert V, Gurlini P, Tosello V, Nagai T, Miyawaki A, Di Lisa F, Pozzan T 2001 Beat-to-beat oscillations of mitochondrial $\left[\mathrm{Ca}^{2+}\right]$ in cardiac cells. EMBO J 20:4998-5007

Rodriguez P, Bhogal MS, Colyer J 2003 Stoichiometric phosphorylation of cardiac ryanodine receptor on serine- 2809 by calmodulin-dependent kinase II and protein kinase A. J Biol Chem 278:38593-38600

Said M, Vittone L, Mundina-Weilenmann C, Ferrero P, Kranias EG, Mattiazzi A 2003 Role of dual-site phospholamban phosphorylation in the stunned heart: insights from phospholamban site-specific mutants. Am J Physiol 285:H1198-H1205

Schmitt JP, Kamisago M, Asahi M, Li GH, Ahmad F, Mende U, Kranias EG, MacLennan DH, Seidman JG, Seidman CE 2003 Dilated cardiomyopathy and heart failure caused by a mutation in phospholamban. Science 299:1410-1413

Schouten VJ 1990 Interval dependence of force and twitch duration in rat heart explained by $\mathrm{Ca}^{2+}$ pump inactivation in sarcoplasmic reticulum. J Physiol 431:427-444

Schroder F, Handrock R, Beuckelmann DJ, Hirt S, Hullin R, Priebe L, Schwinger RH, Weil J, Herzig S 1998 Increased availability and open probability of single L-type calcium channels from failing compared with nonfailing human ventricle. Circulation 98:969-976

Schwinger RH, Bohm M, Schmidt U, Karczewski P, Bavendiek U, Flesch M, Krause EG, Erdmann E 1995 Unchanged protein levels of SERCA II and phospholamban but reduced $\mathrm{Ca}^{2+}$ uptake and $\mathrm{Ca}^{2+}$-ATPase activity of cardiac sarcoplasmic reticulum from dilated cardiomyopathy patients compared with patients with nonfailing hearts. Circulation 92:32203228

Sei CA, Irons CE, Sprenkle AB, McDonough PM, Brown JH, Glembotski CC $1991 \alpha$-Adrenergic stimulation of atrial natriuretic factor expression in cardiac myocytes requires calcium influx, protein kinase C and calmodulin-regulated pathways. J Biol Chem 266:15910-15916 
Sheng M, Thompson MA, Greenberg ME 1991 CREB: a $\mathrm{Ca}^{2+}$-regulated transcription factor phosphorylated by calmodulin-dependent kinases. Science 252:1427-1430

Simmerman HK, Collins JH, Theibert JL, Wegener AD, Jones LR 1986 Sequence analysis of phospholamban. Identification of phosphorylation sites and two major structural domains. J Biol Chem 261:13333-13341

Sipido KR, Volders PG, Vos MA, Verdonck F 2002 Altered $\mathrm{Na}^{+} / \mathrm{Ca}^{2+}$ exchange activity in cardiac hypertrophy and heart failure: a new target for therapy? Cardiovasc Res 53:782-805

Srinivasan M, Edman CF, Schulman H 1994 Alternative splicing introduces a nuclear localization signal that targets multifunctional CaM kinase to the nucleus. J Cell Biol 126:839-852

Sun P, Lou L, Maurer RA 1996 Regulation of activating transcription factor-1 and the cAMP response element-binding protein by $\mathrm{Ca}^{2+} /$ calmodulin-dependent protein kinases type I, II and IV. J Biol Chem 271:3066-3073

Sweeney HL, Bowman BF, Stull JT 1993 Myosin light chain phosphorylation in vertebrate striated muscle: regulation and function. Am J Physiol 264:C1085-C1095

Szalai G, Csordas G, Hantash BM, Thomas AP, Hajnoczky G 2000 Calcium signal transmission between ryanodine receptors and mitochondria. J Biol Chem 275:15305-15313

Taigen T, De Windt LJ, Lim HW, Molkentin JD 2000 Targeted inhibition of calcineurin prevents agonist-induced cardiomyocyte hypertrophy. Proc Natl Acad Sci USA 97:1196-1201

Tian J, Karin M 1999 Stimulation of Elk1 transcriptional activity by mitogen-activated protein kinases is negatively regulated by protein phosphatase $2 \mathrm{~B}$ (calcineurin). J Biol Chem 274:15173-15180

Tokumitsu H, Enslen H, Soderling TR 1995 Characterization of a $\mathrm{Ca}^{2+} /$ calmodulin-dependent protein kinase cascade. Molecular cloning and expression of calcium/calmodulin-dependent protein kinase kinase. J Biol Chem 270:19320-19324

Toyofuku T, Curotto KK, Narayanan N, MacLennan DH 1994 Identification of Ser38 as the site in cardiac sarcoplasmic reticulum $\mathrm{Ca}^{2+}$-ATPase that is phosphorylated by $\mathrm{Ca}^{2+} /$ calmodulindependent protein kinase. J Biol Chem 269:26492-26496

Vega RB, Rothermel BA, Weinheimer CJ, Kovacs A, Naseem RH, Bassel-Duby R, Williams RS, Olson EN 2003 Dual roles of modulatory calcineurin-interacting protein 1 in cardiac hypertrophy. Proc Natl Acad Sci USA 100:669-674

Vittone L, Mundina-Weilenmann C, Said M, Mattiazzi A 1998 Mechanisms involved in the acidosis enhancement of the isoproterenol-induced phosphorylation of phospholamban in the intact heart. J Biol Chem 273:9804-9811

Wegner M, Cao Z, Rosenfeld MG 1992 Calcium-regulated phosphorylation within the leucine zipper of C/EBP $\beta$. Science 256:370-373

Wei SK, Ruknudin A, Hanlon SU, McCurley JM, Schulze DH, Haigney MC 2003 Protein kinase A hyperphosphorylation increases basal current but decreases $\beta$-adrenergic responsiveness of the sarcolemmal $\mathrm{Na}^{+}-\mathrm{Ca}^{2+}$ exchanger in failing pig myocytes. Circ Res 92:897-903

Wencker D, Chandra M, Nguyen K, Miao W, Garantziotis S, Factor SM, Shirani J, Armstrong RC, Kitsis RN 2003 A mechanistic role for cardiac myocyte apoptosis in heart failure. J Clin Invest 111:1497-1504

Wilkins BJ, Molkentin JD 2002 Calcineurin and cardiac hypertrophy: where have we been? Where are we going? J Physiol 541:1-8

Witcher DR, Kovacs RJ, Schulman H, Cefali DC, Jones LR 1991 Unique phosphorylation site on the cardiac ryanodine receptor regulates calcium channel activity. J Biol Chem 266:1114411152

Wright SC, Schellenberger U, Ji L, Wang H, Larrick JW 1997 Calmodulin-dependent protein kinase II mediates signal transduction in apoptosis. FASEB J 11:843-849 
Wu Y, MacMillan LB, McNeill RB, Colbran RJ, Anderson ME 1999 CaM kinase augments cardiac L-type $\mathrm{Ca}^{2+}$ current: a cellular mechanism for long Q-T arrhythmias. Am J Physiol 276: $\mathrm{H} 2168-\mathrm{H} 2178$

Wu Y, Temple J, Zhang R, Dzhura I, Zhang W, Trimble R, Roden DM, Passier R, Olson EN, Colbran RJ, Anderson ME 2002 Calmodulin kinase II and arrhythmias in a mouse model of cardiac hypertrophy. Circulation 106:1288-1293

Xiao R-P, Cheng H, Lederer WJ, Suzuki T, Lakatta EG 1994 Dual regulation of $\mathrm{Ca}^{2+}$ / calmodulin-dependent kinase II activity by membrane voltage and by calcium influx. Proc Natl Acad Sci USA 91:9659-9663

Xu A, Hawkins C, Narayanan N 1993 Phosphorylation and activation of the $\mathrm{Ca}^{2+}$-pumping ATPase of cardiac sarcoplasmic reticulum by $\mathrm{Ca}^{2+} /$ calmodulin-dependent protein kinase. J Biol Chem 268:8394-8397

Yang BF, Xiao C, Roa WH, Krammer PH, Hao C 2003 Calcium/calmodulin-dependent protein kinase II regulation of c-FLIP expression and phosphorylation in modulation of Fas-mediated signaling in malignant glioma cells. J Biol Chem 278:7043-7050

Yaoita H, Ogawa K, Maehara K, Maruyama Y 1998 Attenuation of ischemia/reperfusion injury in rats by a caspase inhibitor. Circulation 87:276-281

Yuan W, Bers DM $1994 \mathrm{Ca}^{2+}$-dependent facilitation of cardiac $\mathrm{Ca}^{2+}$ current is due to $\mathrm{Ca}^{2+}$. calmodulin-dependent protein kinase. Am J Physiol 267:H982-H993

Zhang T, Johnson EN, Gu Y, Morissette MR, Sah VP, Gigena MS, Belke DD, Dillmann WH, Rogers TB, Schulman H, Ross J Jr, Brown JH 2002 The cardiac-specific nuclear $\delta_{\mathrm{B}}$ isoform of $\mathrm{Ca}^{2+} /$ calmodulin-dependent protein kinase II induces hypertrophy and dilated cardiomyopathy associated with increased protein phosphatase 2A activity. J Biol Chem 277:1261-1267

Zhang T, Maier LS, Dalton ND, Miyamoto S, Ross J Jr, Bers DM, Brown JH 2003 The $\delta_{\mathrm{C}}$ isoform of CaMKII is activated in cardiac hypertrophy and induces dilated cardiomyopathy and heart failure. Circ Res 92:912-919

Zhu W, Zou Y, Shiojima I, Kudoh S, Aikawa R, Hayashi D, Mizukami M, Toko H, Shibasaki F, Yazaki Y, Nagai R, Komuro I $2000 \mathrm{Ca}^{2+} /$ calmodulin-dependent kinase II and calcineurin play critical roles in endothelin-1-induced cardiomyocyte hypertrophy. J Biol Chem 275: $15239-15245$

Zhu WZ, Wang SQ, Chakir K, Yang D, Zhang T, Brown JH, Devic E, Kobilka BK, Cheng H, Xiao RP 2003 Linkage of $\beta_{1}$-adrenergic stimulation to apoptotic heart cell death through protein kinase A-independent activation of $\mathrm{Ca}^{2+} /$ calmodulin kinase II. J Clin Invest 111:617625 